\title{
Ophiostomatoid fungi associated with pine bark beetles and infested pines in south-eastern Australia, including Graphilbum ipis-grandicollis
}

\section{sp. nov.}

Conrad Trollip ${ }^{1,2^{*}}$ (D), Angus J. Carnegie ${ }^{3}$, Quang Dinh², Jatinder Kaur², David Smith ${ }^{4}$, Ross Mann², Brendan Rodoni ${ }^{1,2}$ and Jacqueline Edwards ${ }^{1,2}$

\begin{abstract}
The ophiostomatoid fungi are an assemblage of ascomycetes which are arguably best-known for their associations with bark and ambrosia beetles (Curculonidae) and blue stain (sap stain) of many economically important tree species. These fungi are considered a significant threat to coniferous forests, which has resulted in numerous studies characterising the diversity of bark beetles and their ophiostomatoid associates globally. The diversity of ophiostomatoid fungi present in Australian pine plantations, however, remains largely undetermined. The aims of this study were therefore to reconsider the diversity of ophiostomatoid fungi associated with Pinus in Australia, and to establish the baseline of expected taxa found within these plantation ecosystems. To achieve this, we reviewed Australian plant pathogen reference collections, and analysed samples collected during forest health surveillance programs from the major pine growing regions in south-eastern Australia. In total, 135 ophiostomatoid isolates (15 from reference collections and 120 collected during the current study) were assessed using morphological identification and ITS screening which putatively distinguished 15 taxonomic groups. Whole genome sequencing (WGS) of representative isolates from each taxon was performed to obtain high-quality sequence data for multi-locus phylogenetic analysis. Our results revealed a greater than expected diversity, expanding the status of ophiostomatoid fungi associated with Pinus in Australia to include 14 species from six genera in the Ophiostomatales and a single species residing in the Microascales. While most of these were already known to science, our study includes seven first records for Australia and the description of one new species, Graphilbum ipis-grandicollis sp. nov.. This study also provides an early example of whole genome sequencing (WGS) approaches replacing traditional PCR-based methods for taxonomic surveys. This not only allowed for robust multi-locus sequence extraction during taxonomic assessment, but also permitted the rapid establishment of a curated genomic database for ophiostomatoid fungi which will continue to aid in the development of improved diagnostic resources and capabilities for Australian biosecurity.
\end{abstract}

Keywords: Ceratocystiopsis, Graphilbum, Leptographium, Ophiostoma, Raffaelea, Sporothrix, Graphium, One new taxon

*Correspondence: conrad.trollip@agriculture.vic.gov.au

${ }^{2}$ Department of Jobs, Precincts and Regions, Agriculture Victoria

Research, AgriBio Centre, Bundoora, VIC 3083, Australia

Full list of author information is available at the end of the article

\section{Introduction}

Fungi within Ophiostomatales and Microascales are best known for their associations with arthropod vectors and include examples of some of the most devastating fungalinsect symbioses known to plant pathologists over the past century (Fisher et al. 2012; Wingfield et al. 2017b; 
Brasier and Webber 2019). Notable examples include the Dutch elm disease pathogens, Ophiostoma ulmi and $O$. novo-ulmi (Santini and Faccoli 2015; Brasier and Webber 2019), the laurel wilt pathogen Raffaelea lauricola (Harrington et al. 2008) as well as the numerous pathogens belonging to Ceratocystis which cause tree mortality in natural and agricultural ecosystems (Roux et al. 2007; Wingfield et al. 2017b; Tsopelas et al. 2017). In a recent review on novel associations for members of Ophiostomatales and Microascales, Wingfield et al. (2017b) highlight the numerous biological and anthropogenic factors that influence the dispersal of these fungi and their vectors globally; a major feature of the ever-increasing threat these fungi pose to global biosecurity.

Despite being formally recognised as two distinct orders in the Sordariomycetes, species belonging to Ophiostomatales and Microascales share a long and complicated taxonomic history and are collectively referred to as the ophiostomatoid fungi (Wingfield et al. 1993; Seifert et al. 2013). This is due to similarities shared across their biology, particularly in key morphological characters, that is believed to have been driven by convergent evolution in adaptation to insect-mediated dispersal (De Beer et al. 2013; Wingfield et al. 2017b). Ophiostomatoid fungi are commonly associated with bark (Coleoptera: Scolytinae) and ambrosia (Curculonidae: Scolytinae, Platypodinae) beetles (Kirisits 2004; Hofstetter et al. 2015), where a greater dependency and specificity is apparent for Ophiostomatales compared to Microascales (Wingfield et al. 2017b). Ophiostomatoid genera that are most commonly associated with beetles include: Ambrosiella, Endoconidiophora and Graphium in Microascales; and Affroraffaelea, Aureovirgo, Ceratocystiopsis, Fragosphaeria, Graphilbum, Leptographium, Ophiostoma, Raffaelea, and Sporothrix of Ophiostomatales (Hyde et al. 2020).

While not all ophiostomatoid fungi are responsible for tree mortality, many are well recognized as the causal agents of blue stain (sap stain) in the wood of economically important tree hosts (Kirisits 2004; Seifert et al. 2013). This is particularly true for pine (Pinus) plantations globally (Seifert et al. 2013; de Errasti et al. 2018; Jankowiak et al. 2021). Systematic surveys of bark beetles and ophiostomatoid fungi associated with pine have been completed in North and Central America (Zhou et al. 2004a; Kim et al. 2011; Klepzig and Hofstetter 2011; Taerum et al. 2013; Marincowitz et al. 2020), Europe (Linnakoski et al. 2012; Romón et al. 2014; Jankowiak et al. 2012, 2020), Asia (Zhou et al. 2013; Masuya et al. 2013; Kirisits et al. 2013), with a significant number of surveys conducted recently in China (Chang et al. 2017, 2019; Wang et al. 2018, 2019, 2020), South America (Zhou et al. 2004b; de Errasti et al. 2018) and New Zealand (Thwaites et al. 2005, 2013). The diversity of ophiostomatoid fungi present in exotic pine plantations in Australia, however, remains largely undetermined.

Since its first detection in the 1960s (Vaartaja 1967), Ophiostoma ips has been regarded as the most common fungal species associated with blue stain and pine bark beetles (specifically Ips grandicollis) in Australia (Stone and Simpson 1987, 1990; Hood and Ramsden 1997; Zhou et al. 2007; Carnegie et al. 2019). Additionally, surveys of the fungal associates of Ips grandicollis on Pinus taeda and P. elliottii in New South Wales (NSW) in the late 1980s serve as the first reports of a Ceratocystiopsis and Graphilbum species detected in Australian pine plantations (Stone and Simpson 1987, 1990), while Grosmannia huntii was first reported in NSW in 1998 (Jacobs et al. 1998). To date, these serve as the few detailed surveys of fungi associated with Australian pine bark beetles. Other, somewhat incidental records include the detection of Ophiostoma floccosum, O. quercus and an unknown species reported as a Pesotum aff. fragrans, all isolated from woodchips of $P$. radiata from the Tantanoola paper mill in South Australia (Harrington et al. 2001; Thwaites et al. 2005). Evidently, the historical record of ophiostomatoid fungi in Australian pine plantations has relied heavily on morphology, and/or the association of blue stain in the presence of the pine bark beetle, I. grandicollis (Carnegie and Nahrung 2019; Carnegie et al. 2019). Interestingly, the introduction of $I$. grandicollis in 1943 coincides with the introduction of two other exotic pine bark beetles, namely Hylastes ater and Hylurgus ligniperda in 1936 and 1942, respectively (Nahrung et al. 2016). Both are known to also vector ophiostomatoid fungi (Kim et al. 2011; de Errasti et al. 2018). The above-mentioned pine bark beetles, along with their associated ophiostomatoid fungi, are considered as established exotics to Australia.

Recent efforts to improve on the capacity of forest biosecurity surveillance, through programs such as the forest health surveillance program, and the more targeted highrisk site surveillance program (Carnegie et al. 2018), has led to several detections of cryptic fungal species associated with pine bark beetles and blue stain in NSW (Carnegie and Nahrung 2019). This includes the recent pest detections of Graphilbum fragrans, $O$. angusticollis, $O$. pallidulum and Sporothrix cf. abietina, illustrating the value of targeted surveillance programs for the detection of novel pests (Carnegie et al. 2019). These findings also emphasize the need for an updated record of the diversity of established ophiostomatoid fungi associated with Australian pine and pine bark beetles.

The overall aim of this study was to reconsider the diversity of ophiostomatoid fungi associated with pine and pine bark beetles in south-eastern Australia. In order to achieve this, we looked to: (1) review all available ophiostomatoid reference material previously reported from 
pine and lodged in Australian plant pathogen reference collections; (2) survey the ophiostomatoid fungi found in pine plantations during the 2019-2020 forest health surveillance period; and (3) use whole genome sequencing (WGS) of representative taxa to establish a curated database for improved molecular diagnostics of ophiostomatoid fungi for Australian biosecurity.

\section{Materials and methods}

\section{Literature and Australian plant pathogen reference collection review}

Ophiostomatoid fungi previously collected from Pinus spp. in Australia were included as references in this study. Living cultures were recovered from the Victorian Plant Pathology Herbarium (VPRI) and the New South Wales (NSW) Plant Pathology and Mycology Herbarium (DAR) following database searches using the currently accepted nomenclature (Seifert et al. 2013) and all putative synonyms (MycoBank Database, www.mycobank.org; Species Fungorum, www.speciesfungorum.org) of ophiostomatoid fungi that were recorded in the respective Australian collections and associated with Pinus. Additionally, a literature and GenBank database search (http://www. ncbi.nlm.nih.gov) was performed for Australian specimens previously reported from Pinus in order to identify additional specimens that had publicly available DNA sequence data.

\section{Sample collection during forest health surveillance}

Annual forest health surveillance programs are conducted in pine plantations across Australia, including NSW (Carnegie et al. 2008), Victoria (Smith et al. 2008), Tasmania (Wotherspoon 2008), and South Australia (Phillips 2008). These surveillance programmes capture a broad overview of plantation health, achieved through aerial and ground surveys across the major growing regions for each state. Taking advantage of this routine surveillance, sampling was concentrated on pine trees showing typical symptoms of bark beetle infestation, which included any dead or dying trees, but also tree stumps in recently harvested sections. Samples were either collected and sent in by respective state agencies conducting the surveillance, or by the first author accompanying forest health surveillance. Samples collected from May 2019 to March 2020 originated from 40 locations, including collections from NSW $(n=34)$, Victoria $(n=2)$, Tasmania $(n=2)$, and South Australia $(n=2)$ (Additional file 1: Table S1). Samples of sapwood and/or pieces of bark containing beetle galleries were collected and individually placed into sampling bags to retain moisture. Where possible, pine bark beetles were collected into $50 \mathrm{ml}$ collection vials on site using forceps and submitted along with their respective wood samples.
Finally, all wood submissions were screened upon arrival in the laboratory for any remaining beetles that may have been concealed within the galleries. Pine bark beetles present in each sample were sorted into morphospecies, pooled and then treated as a single submission (representative specimens were morphologically identified by Crop Health Services diagnostics unit, Agriculture Victoria). All samples were stored at $4{ }^{\circ} \mathrm{C}$ until they were processed for fungal isolations.

\section{Fungal isolations}

Fungal isolations from beetle galleries were performed by directly transferring aerial mycelia and/or spore masses found on sporing structures characteristic of ophiostomatoid fungi, such as ascomata or synnemata, onto malt extract agar (MEA; Oxoid MEA as per manufacturer instructions; Oxoid, Basingstoke, UK) amended with $0.1 \mathrm{~g}$ Tetracycline (Fluka Analytical, Sigma-Aldrich, MO, USA) per $1000 \mathrm{ml}$ of media. When sporing structures were absent, samples were incubated in moistened plastic containers at room temperature for approximately 21 days to encourage sporulation. When blue stained sapwood was present in a sample, wood chips of approximately $5 \times 5 \mathrm{~mm}$ were cut, surface sterilized with $1.5 \%$ sodium hypochlorite for $1 \mathrm{~min}$, and plated onto MEA. Beetle isolations followed an amended protocol from Alamouti et al. (2006). Beetles from each sample were vortexed in $1 \mathrm{ml}$ of $0.01 \%$ Tween 80 solution (Nuplex Industries, South Australia, Australia) for $3 \mathrm{~min}$. Thereafter, spore suspensions were spread onto MEA plates and incubated at $22{ }^{\circ} \mathrm{C}$ in the dark for $7 \mathrm{~d}$ during which all germinating single spores and hyphal tips were transferred onto individual MEA plates, producing axenic cultures which were maintained under the same growing conditions.

\section{Preliminary identification and ITS screening}

Isolates were preliminarily grouped based on culture morphology and growth on MEA. In addition to this, a Chelex-based internal transcribed spacer (ITS) region sequencing protocol was used to confirm the putative identification of all ophiostomatoid fungi. In order to achieve this, a small amount of mycelia was scraped from each isolate using a sterile needle tip and placed into individual $200 \mu \mathrm{l}$ reaction tubes containing $100 \mu \mathrm{l}$ of molecular biology grade Chelex 100 resin (Bio-Rad Laboratories, Hercules, CA, USA) following a modified protocol for Chelex DNA preparation (Walsh et al. 1991). The ITS region was PCR amplified using the ITS1F and ITS4 primers (White et al. 1990; Gardes and Bruns 1993). PCR reactions included $3 \mu$ l Chelex DNA template, $15 \mu \mathrm{l}$ of MyTaq Red mix (Bioline, London, UK), 0.4 $\mu \mathrm{M}$ of each primer (forward and reverse) and were made up to a 
final volume of $30 \mu \mathrm{l}$ with nuclease free water. PCR cycle conditions followed those of Duong et al. 2012. PCR products were sent for purification and sequencing at Macrogen (Seoul, Rep. of Korea). All resulting sequences were trimmed, aligned and analysed using Geneious Prime ${ }^{\circledR}$ 2019.1.3 (www.geneious.com). Sequences were BLASTn searched against the $\mathrm{nr} / \mathrm{nt}$ database of the NCBI to confirm placement within either the Ophiostomatales or Microascales. Only ophiostomatoid fungi were retained for further analysis. Finally, isolates from a given sample that shared an ITS sequence and belonged to the same morphological group were considered the same fungus, with a single axenic culture being chosen as the representative isolate in each case.

\section{DNA extraction, whole genome sequencing and phylogenetic analysis}

Seven to $10 \mathrm{~d}$ old cultures were inoculated into $40 \mathrm{~mL}$ Potato Dextrose Broth (PDB; 9.6 g Oxoid PDB, $400 \mathrm{~mL}$ deionized water; Oxoid, Basingstoke, UK) and grown on a shaking incubator at $150 \mathrm{rpm}$ at room temperature for approximately $72 \mathrm{~h}$. Mycelia were then harvested using autoclaved Miracloth (Merck, Darmstadt, Germany) and freeze-dried before DNA extraction using the Promega Wizard Genomic DNA Purification Kit (Promega, Madison, WI, USA). The quality and quantity of extracted DNA was assessed using a Nanodrop 1000 (Thermo Fisher Scientific, MA USA) and Quantus fluorometer (Promega, Madison, WI, USA), respectively. Libraries with an average insert size of 300 bp were generated using the NextFlex Rapid XP DNA-Seq Kit (Perkin Elmer, Austin, TX, USA). Whole genome sequencing (WGS) was performed on the Novaseq 6000 system (Illumina, San Diego, CA, USA). Raw sequencing reads were quality checked and trimmed using FastP (Chen et al. 2018). Following quality trimming, initial de novo genome assemblies were produced using SPAdes v3.14.1 (Nurk et al. 2013). Assemblies were performed on error-corrected reads with a kmer range of 33, 55, 77, 97 and 111.

Assembled genomes provided a platform for sequence extraction of commonly used barcoding loci, including the ITS, the large subunit of ribosomal DNA (LSU), betatubulin (BT), translation elongation factor 1- $\alpha$ (TEF), and the calmodulin (CAL) regions. For each locus, reference sequences for type collections of ophiostomatoid fungi available in GenBank were used to create reference sets. Sequencing reads for each isolate were subsequently mapped against each reference set using BBMap (Bushnell (2014); sourceforge.net/projects/bbmap/). Locusspecific binned reads were generated for each isolate, and these reads were then mapped back to the respective de novo assembled genome in order to extract the assembled locus. This mapping step served as an additional check point to ensure cultures were axenic and only a single sequence was generated from the consensus of all mapped reads using a minimum of $10 \times$ coverage. Extracted loci were then BLASTn searched to confirm taxonomic affinities and obtain similar sequences from GenBank to be included in phylogenetic analyses along with the sequences of type ophiostomatoid fungi.

For multi-locus phylogenetic analysis, the ITS and LSU datasets were used for initial placement of Australian isolates within well-defined species complexes of Ophiostomatales and Microascales. Subsequent phylogenetic analyses of the $\mathrm{BT}, \mathrm{TEF}$ and CAL regions were performed within each species complex where loci were chosen based on availability of reference data from previous studies (e.g. BT and CAL for Sporothrix) which allowed for more accurate delineation of the Australian taxa. Sequence alignments were performed with MAFFT v7.388 using the E-INS-i algorithm and a gap open penalty of 1.53 (Katoh et al. 2019). The scoring matrix for alignments spanning across multiple genera was $200 \mathrm{PAM} / \mathrm{k}=2$, while for within genus analyses the scoring matrix was set at $1 \mathrm{PAM} / \mathrm{k}=2$ (Linnakoski et al. 2012; Katoh et al. 2019). All aligned sequence datasets were submitted to TreeBase (No. 27096). Maximum Likelihood (ML) analysis was performed with RAxML v8.2.11 (Stamatakis 2014), using the GTR model with optimization for substitution rates and the estimation of rate heterogeneity (GAMMA) specified, while the proportion of invariable sites $(+I)$ was selected based on results of model estimation using Smart Model Selection (SMS; Lefort et al. (2017); available at http://www. atgc-montpellier.fr/sms/). Confidence support was estimated with bootstrapping of 1000 replicates. Bayesian Inference (BI) analyses were done using MrBayes 3.2.6 (Huelsenbeck and Ronquist 2001). The substitution models and estimated rate parameters, estimated with SMS, were then included manually in MrBayes. Four Markov chain Monte Carlo (MCMC) chains were run at the same time from a random starting tree for 5000000 iterations. Trees were sampled every 100 generations with a burnin length of $25 \%$. Posterior probabilities were calculated from a majority rule consensus tree.

\section{Taxonomy}

Morphological studies were performed on selected isolates belonging to putative novel lineages identified following phylogenetic analysis. Cultures were grown at $22^{\circ} \mathrm{C}$ on $2 \%$ MEA (33 g Oxoid MEA, 10 g Oxoid agar, $1 \mathrm{~L}$ deionized water), as well as water agar (WA; 15 g Oxoid agar; $1 \mathrm{~L}$ deionized water) amended with autoclaved pine needles in order to encourage sporulation. Subsequently, reproductive structures were mounted on glass slides with $85 \%$ lactic acid and examined using Leica DM6B 
and M205C microscopes (Leica, Heerbrugg, Switzerland). Measurements of taxonomically characteristic structures (approximately fifty measurements for each character wherever possible) were made using a mounted Leica camera operated using the Leica application suite software v 3.06. Measurements are presented as, (minimum-) (mean-standard deviation) - (mean + standard deviation) (- maximum).

\section{Genomes of representative species of ophiostomatoid fungi from Australian pine plantations}

Draft genomes of representative isolates for each ophiostomatoid taxon collected in this study were subjected to genome quality assessments using QUAST v5.0.2 (Mikheenko et al. 2018). In order to perform suitable comparisons, the QUAST analyses also included publicly available genomes of ophiostomatoid fungi that corresponded to the genera obtained during this study. This was done to update genome completeness assessments against the latest lineage-specific datasets available for BUSCO (Benchmarking Universal Single-Copy Orthologs tool, BUSCO; https://busco.ezlab.org/), as well as to assess gene predictions using a single prediction tool (GenMark-ES run in fungal mode). BUSCO models were predicted using the Sordariomycetes_odb10 lineage coupled with the Augustus species parameter option set as Neurospora crassa. Draft genome data for the representative isolates sequenced in this study has been deposited at DDBJ/EMBL/GenBank under BioProject PRJNA667796. The accession numbers for each genome are presented in Table 3.

\section{Results}

\section{Sample collection and fungal isolation}

A total of 135 ophiostomatoid isolates were collected during this study, 15 of which were obtained from Australian plant pathogen reference collections (Table 1). The reference isolates available from Australian collections included five Ophiostoma ips, five Sporothrix sp. (three of which were putatively identified as $S$. cf. abietina), two isolates residing within Leptographium s.lat. (one isolate, DAR 84705, identified as Gro. huntii), two identified as $O$. angusticollis, and a single G. fragrans isolate.

The remaining 120 isolates were obtained from samples received during the 2019-20 forest health surveillance period, which included isolations from beetles, beetle galleries and blue-stained wood chips (Additional file 1: Table S1). Samples were largely collected from Pinus radiata (62.5\%), the most common Pinus species grown across temperate regions of south-eastern Australia, and P. caribaea $\mathrm{x}$ elliottii hybrids (22.5\%), the most commonly planted species in the subtropical parts of northern NSW. The remainder were collected from P. taeda (7.5\%),
P. elliottii (5\%), and included a single sample from an amenity planting of $P$. ponderosa. Three species of pine bark beetles, namely Ips grandicollis, Hylastes ater and Hylurgus ligniperda, and the ambrosia beetle Xyleborus nr. ferrugineus., were recovered from 22 of the samples collected (Additional file 1: Table S1). Ips grandicollis was the most abundant beetle species sampled during this study, comprising approximately $97 \%$ of the beetles included in our dataset. Samples containing $H$. ater and Hy. ligniperda came only from sites in South Australia and Tasmania respectively, while a single sample from northern NSW included the Xyleborus species.

Preliminary identification and ITS screening characterised the 120 ophiostomatoid isolates into 15 taxonomic groups, 14 of which resided in , and a single taxon belonged to Microascales (Table 1). Ophiostomatoid isolates were recovered evenly from the sampled pine tissue (56\%) and bark beetles (44\%), with about two thirds of all isolations associated with a $P$. radiata host (Additional file 2: Table S2). Ophiostoma ips (Taxon 9) and Sporothrix pseudoabietina (Taxon 14) were isolated most frequently, making up approximately $53 \%$ and $19 \%$ of the dataset, respectively (Additional file 2: Table S2). This trend was consistent for the abundantly sampled bark beetle vector, Ips grandicollis, where five additional taxa (taxa 1, 3, 4,8 and 15) were represented by the 44 fungal isolates collected from this source. The remaining taxa were only recovered occasionally, with the host association and isolation frequencies recorded in Additional file 2: Table S2. Finally, 46 isolates representing all major taxonomic groups were selected for further phylogenetic analysis and taxonomic placement (Table 1).

\section{Phylogenetic analysis}

Phylogenetic analysis of the ITS (Fig. 1) and LSU (Fig. 2) regions allowed for taxa to be sorted into their respective species complexes, while the additional gene regions of BT, TEF and CAL (Figs. 3, 4, 5, 6, 7, 8, Additional files 4 and 5: Fig. S1, S2) enabled species level resolution and more accurate delineation. In Ophiostomatales, the 14 taxonomic groups were found to encompass six genera: Ceratocystiopsis (Taxon 1), Graphilbum (Taxa 2-4), Leptographium s. lat. (Taxa 5-6), Ophiostoma s. lat. (Taxa 7-10), Raffaelea (Taxon 11), and Sporothrix (Taxa 12-14). The single taxon residing in Microascales was identified as belonging to Graphium (Taxon 15).

\section{Ophiostomatales}

Taxon 1 comprised of four representative isolates grouping as a well-supported clade within Ceratocystiopsis (Figs. 2, 3). Phylogenetic analysis of the LSU dataset revealed Taxon 1 grouped as an independent lineage, close to Ceratocystiopsis (Cop.) ranaculosa and Cop. 


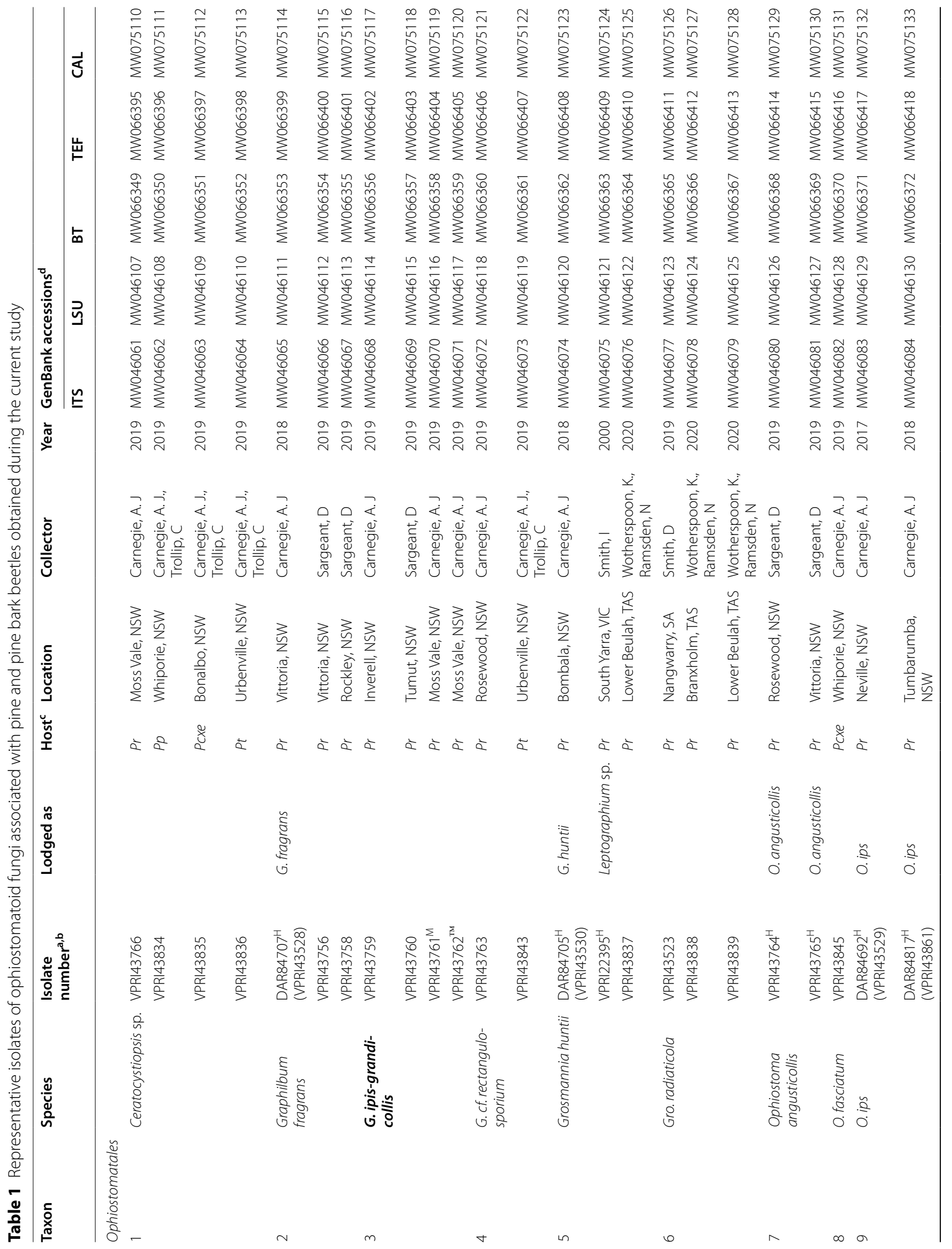




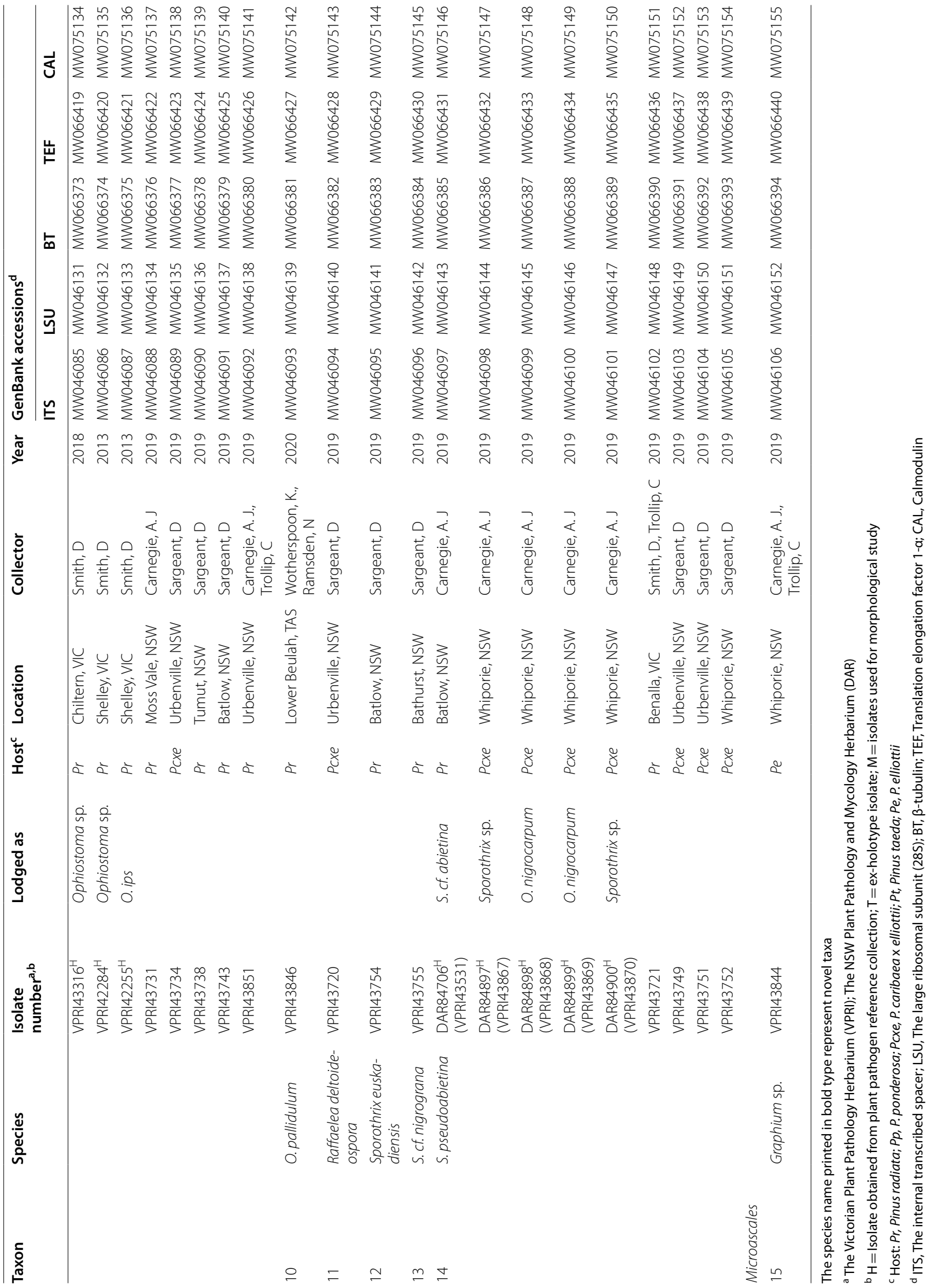




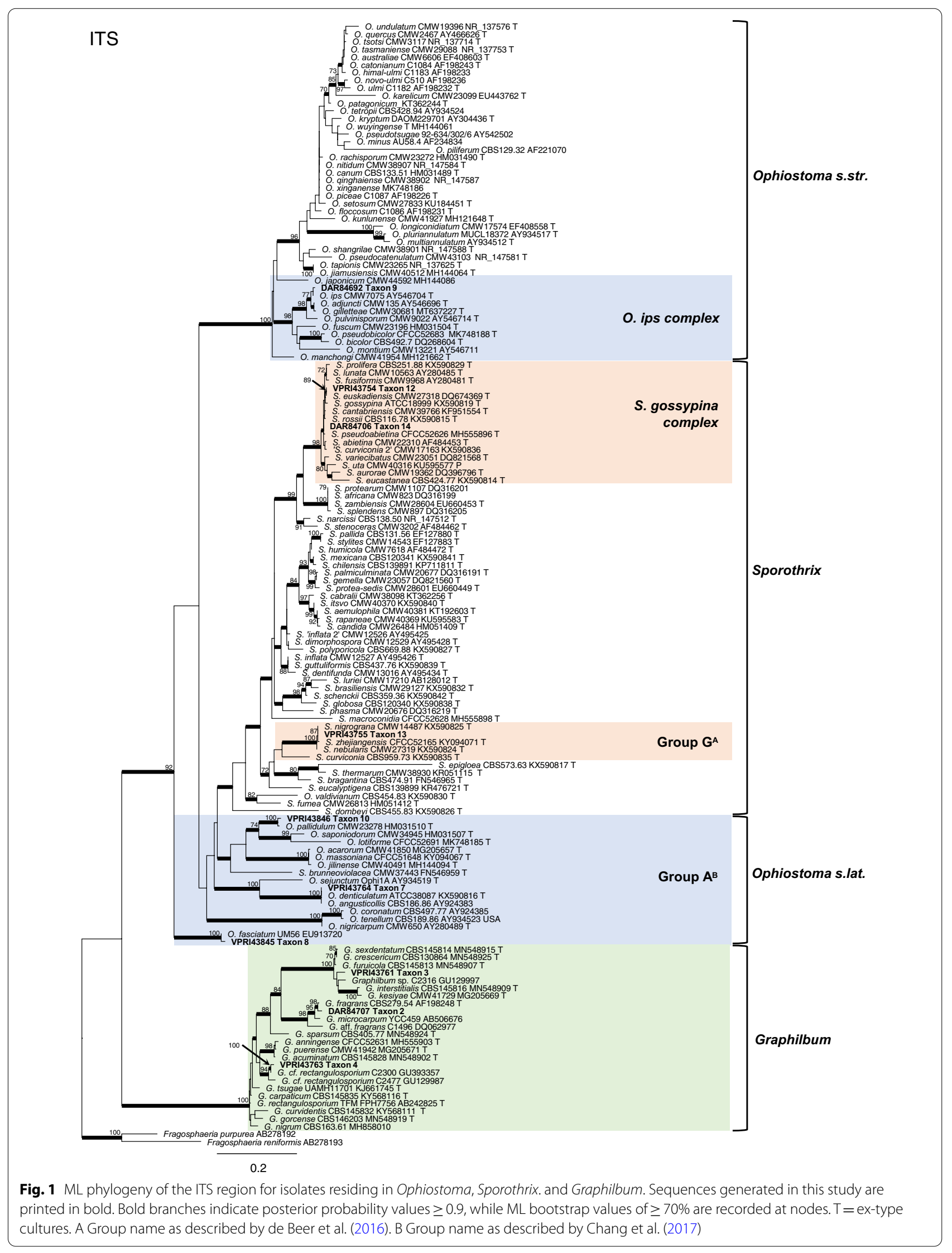




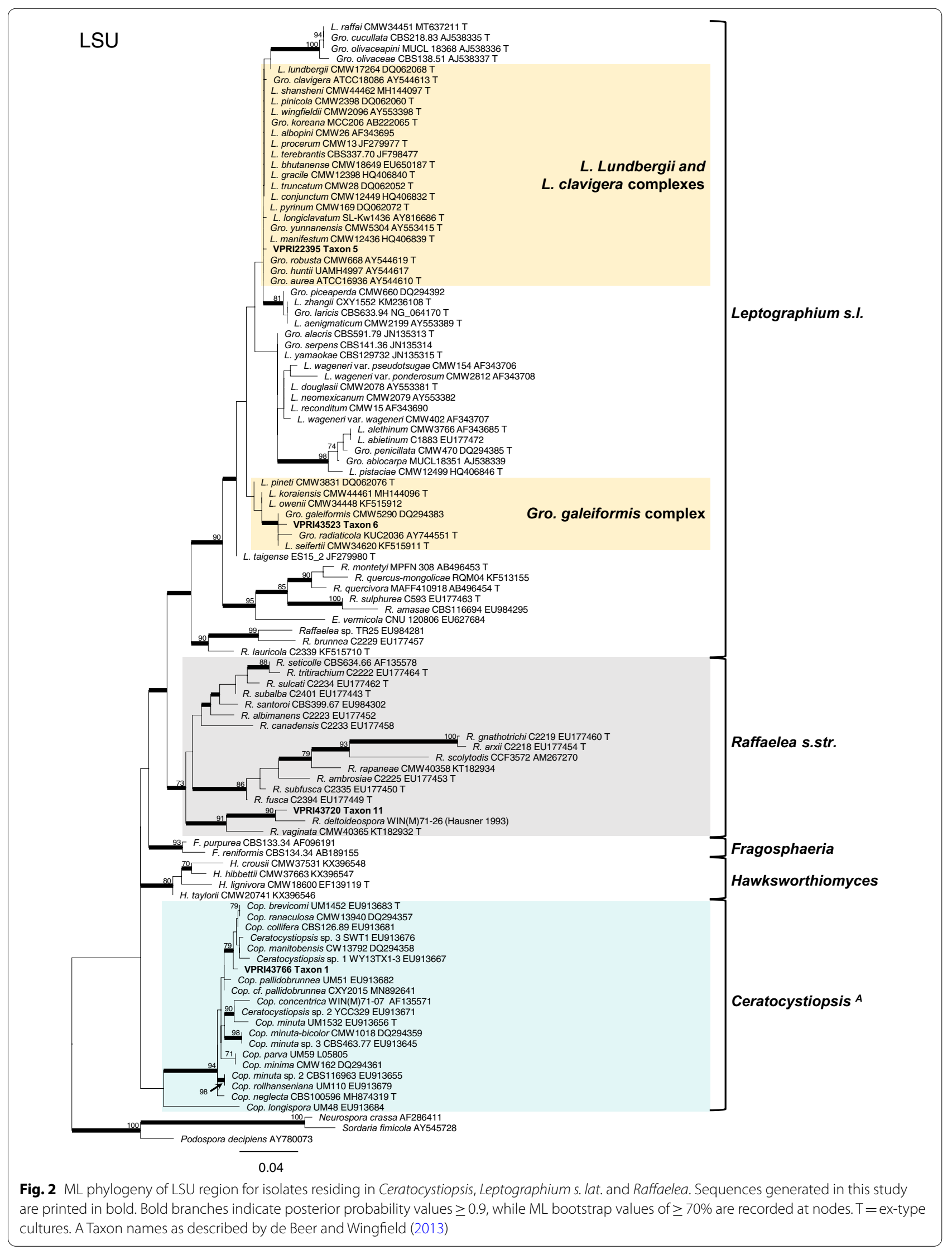




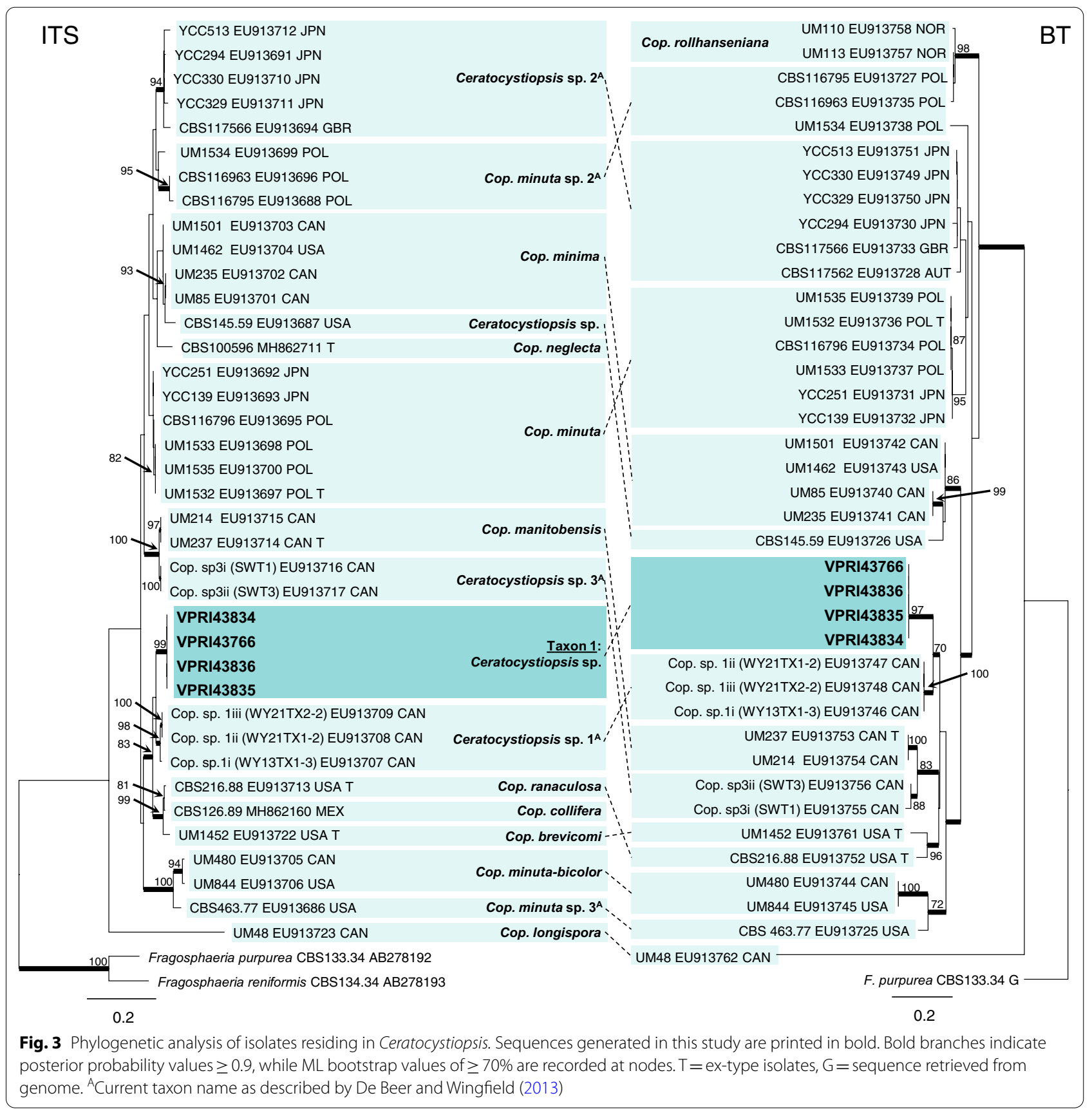

brevicomis (Fig. 2). Analysis of ITS and BT regions (Fig. 3) supports this placement and illustrates that the Australian isolates are most closely related to a previously undescribed taxon reported as Ceratocystiopsis species 1 (Cop. minuta-like) from Canada (Plattner et al. 2009). Multi-locus analysis suggests the isolates of Ceratocystiopsis sp. (Taxon 1) represent a novel lineage.

Three taxa (Taxa 2, 3 and 4) residing within Graphilbum were collected during this study (Fig. 1). Reference collection isolate DAR84707 and two representative isolates collected during this survey forming Taxon 2 (Table 1) were confirmed as Graphilbum fragrans (Figs. 1, 4). Taxon 3 and 4 (which comprised of four and two isolates, respectively; Table 1) were both preliminarily identified as G. cf. rectangulosporium isolates, with BLASTn searches suggesting an affiliation to previously reported isolates from the USA, China, and Europe. Further analysis of the BT, TEF and CAL regions (Figs. 1, 4, Additional file 4: Fig. S1) revealed that Taxon 3 represented a phylogenetically distinct lineage, forming part of a species 


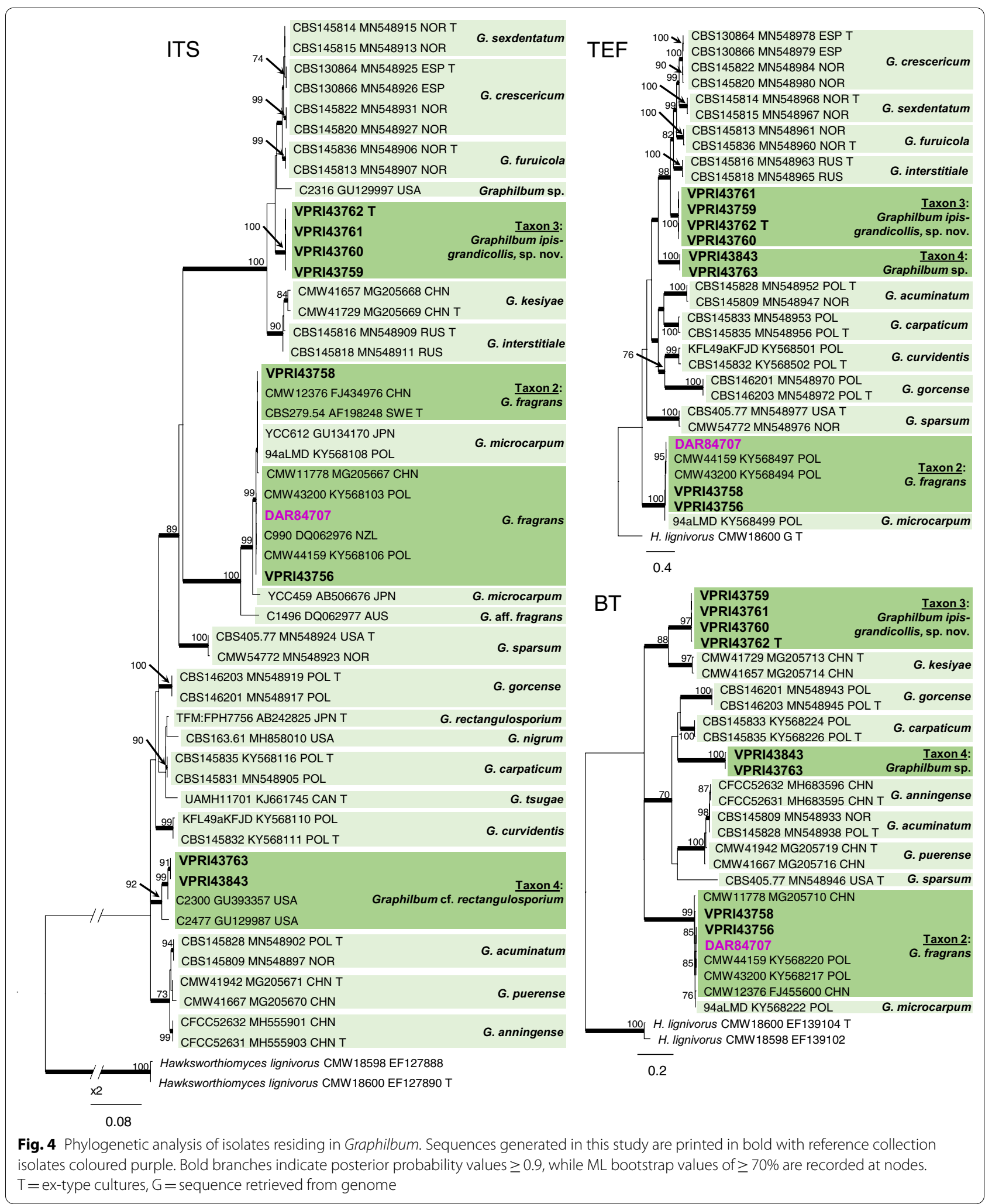


complex including G. crescericum, G. furuicola, G. interstitiale, G. kesiyae, and G. sexdentatum. This new species is described below. Taxon 4 formed a well-supported clade with two previously undescribed Graphilbum isolates reported from the USA (Fig. 4).

Within Leptographium s.l., two taxa (Taxa 5 and 6) were collected (Table 1; Fig. 2). Taxon 5 comprised of two reference collection isolates, as well as a single isolate collected during this survey. Phylogenetic analysis confirmed Taxon 5 as Grosmannia huntii (Figs. 2, 5a). Taxon 6 comprised of three representative isolates which fell into a clade within the Gro. galeiformis species complex (Fig. 2). Analysis of BT and TEF confirmed the delineation of Taxon 6 as the species Gro. radiaticola (Fig. 5b).

Taxa 7 to 10 resided within Ophiostoma s. lat. with Taxon 9 the only one belonging to a well-recognised species complex (Fig. 1). Taxon 9 included the reference collection isolates DAR84692, DAR84817, VPRI42284, VPRI42255 and VPRI43316, along with five additional isolates collected during this study (Table 1). Analysis of the ITS region identified Taxon 9 isolates as Ophiostoma ips (Fig. 1). Despite incongruence with regards to the delimitation of $O$. ips using ITS alone, BT analysis confirmed little variation between the Australian isolates, and established a clear grouping with several isolates recently confirmed as $O$. ips (Fig. 6a). Taxa 7, 8 and 10 all grouped peripherally to Ophiostoma s. str. and are regularly referred to as Group A/Lineage G (Chang et al. 2017; Wang et al. 2020). Taxon 7 included two reference collection isolates forming a lineage along with two species, namely $O$. angusticollis and O. denticulatum (Fig. 6b). The currently available molecular data for reference specimens within this lineage is lacking for appropriate taxonomic comparison, and thus clear differentiation between these species is limited. For now, Taxon 7 is referred to as $O$. angusticollis. Taxon 8 included a single isolate collected during this study (Table 1), with ITS and BT analyses identifying this taxon as O. fasciatum (Figs. 1, 6b). Taxon 10 included a single strain preliminarily identified as O. pallidulum (Fig. 1). BT analysis further confirmed this identification (Fig. 6b).

The single isolate of Taxon 11 grouped within Raffaelea s. str. (Fig. 2). Analysis of the LSU sequence showed that the Australian isolate forms a well-supported lineage with Raffaelea deltoideospora (Fig. 2). Analysis of the ITS region further validated Taxon 11's placement within
Raffaelea s. str. and the delimitation of this species as $R$. deltoideospora (Additional file 5: Fig. S2).

Three Sporothrix taxa were obtained during this study (Taxa 12, 13, and 14; Table 1). Taxon 12 and Taxon 14 both grouped within the S. gossypina complex (Fig. 1). While analysis of the ITS region gave limited resolution within the S. gossypina complex (Fig. 1), analysis of BT and CAL was able to distinguish between the closely related species (Fig. 7a). The single isolate of Taxon 12 was identified as S. euskadiensis (Romón et al. 2014). Taxon 14 included all reference collection Sporothrix isolates as well as 5 additional representative isolates collected during this study (Table 1). ML analysis placed isolates of Taxon 14 in a well-supported clade alongside the type strain of S. pseudoabietina (Fig. 7a). Taxon 13 comprised of a single isolate collected in this study, with the ITS region placing the taxon among species belonging to a group within Sporothrix recently referred to as "Group G" (De Beer et al. 2016) (Fig. 1). Taxon 13 shared an almost identical ITS sequence with the type sequences for S. nigrograna and S. zhejiangensis (Fig. 7b). While analysis of the BT region was unable to clearly distinguish between S. nebularis and S. zhejiangensis (Fig. 7b), analysis of CAL did show good support for the distinction of Taxon 13 from S. nebularis (Additional file 6: Fig. S3). A lack of available molecular data for these species limited further phylogenetic comparisons and thus, the placement of the Australian taxon.

\section{Microascales}

The single isolate (Taxon 15) residing in Microascales was identified as a Graphium species (Fig. 8). Analysis of ITS and TEF regions revealed that this isolate resides closely to the species of Gra. basitruncatum and Gra. carbonarium (Fig. 8). While this taxon may represent a novel lineage, we have chosen not to formally describe it until additional specimens and/or reference material can be examined. Taxon 15 is thus referred to as a Graphium species.

\section{Species of Ophiostomatales and Microascales associated with Australian Pinus, verified by DNA sequence data}

Revision of the literature, as well as the database search, allowed for the comparison of our results to the historical records of ophiostomatoid fungi associated with Pinus in Australia (Table 2). While several taxa identified in the

(See figure on next page.)

Fig. 5 Phylogenetic analysis of BT and TEF for Leptographium s.lat. a. Isolates residing in the L. lundbergii and Gro. huntii species complexes. b. Isolates residing in the Gro. galeiformis species complex. Sequences generated in this study are printed in bold, with reference collection isolates coloured blue. Bold branches indicate posterior probability values $\geq 0.9$, while ML bootstrap values of $\geq 70 \%$ are recorded at nodes. $T=$ ex-type cultures 
a $\mathrm{BT}$

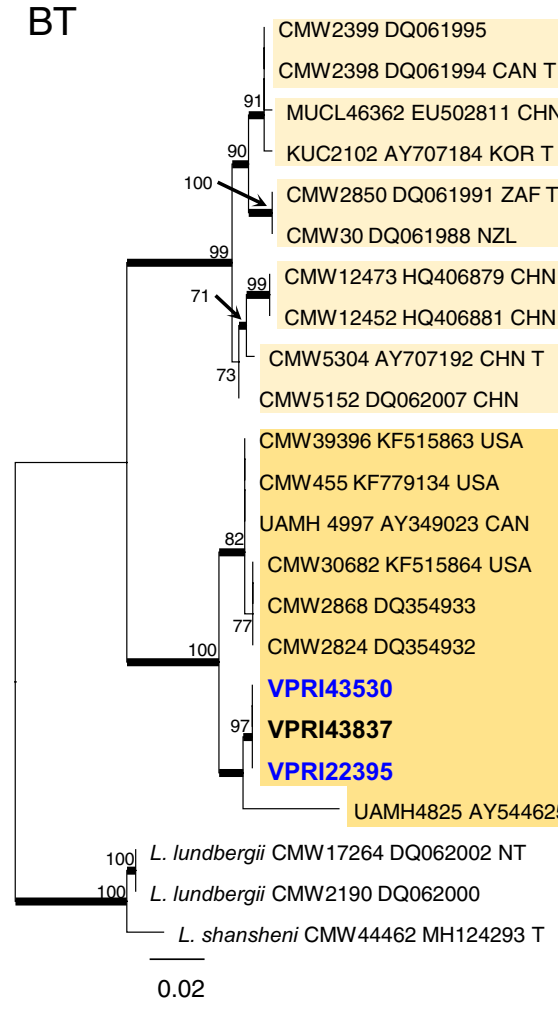

L. pinicola -....-.

Gro. koreana-...........

L. truncatum -

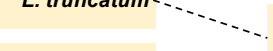

L. conjunctum -

.... . . CMW12473 HQ

Gro. yunnanense CMW12449 HQ406856 CHN

CMW2399 DQ062028 CAN 196

TEF

CMW2398 DQ062027 CAN T

MUCL46362 EU502826 CHN 83

KUC2102 EU502827 KOR T

CMW1873 DQ062030 JPN

CMW30 DQ062021 NZL

CMW2850 DQ062024 ZAF T

CMW5304 AY536209 CHN T

CMW5152 DQ062040 CHN 100

UAMH4997 AY544640 CAN

CMW39396 KF515890 USA

CMW30682 KF515889 USA

Gro. huntii

VPRI43530

VPRI43837

CMW2868 DQ354938

CMW2824 DQ354937 100

VPRI22395

UAMH4825 AY544641 CAN

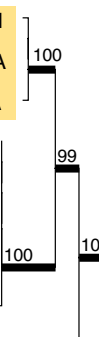

L. lundbergii CMW2190 DQ062033 7100

L. lundbergii CMW17264 DQ062035 T

L. shansheni CMW44462 MH124373 T

0.02

b

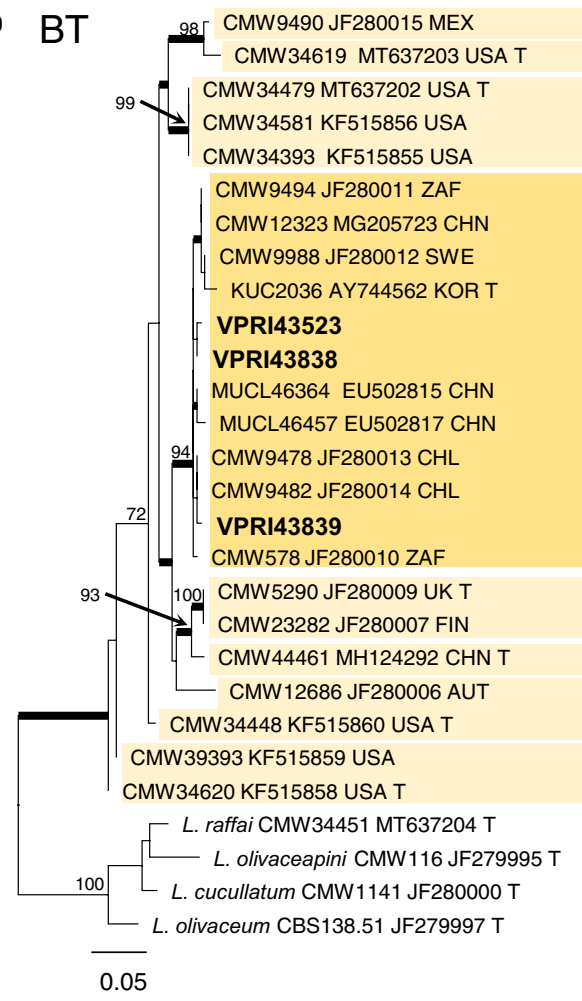

Grosmannia sp.--

L. gordonii--.-- - -

L. doddsii-

CMW9490 JF280053 MEX CMW34619 MT637207 USA T CMW34393 KF515881 USA CMW34479 MT637205 USA T CMW34581 KF515882 USA CMW34448 KF515884 USA T CMW34620 KF515885 USA T CMW39393 KF515886 USA CMW578 JF280054 ZAF

Taxon 6: Gro. raxon 6:

\section{VPRI43523}

CMW9494 JF280055 ZAF 99

CMW12323 MG205764 CHN

VPRI43839 VPRI43838

CMW9482 JF280058 CHL CMW9478 JF280057 CHL CMW9988 JF280056 SWE CMW12686 JF280052 AUT CMW5290 JF280060 UK T CMW23282 JF280059 FIN 78 CMW44461 MH124372 CHN T

L. olivaceapini CMW116 JF280038 T L. olivaceum CBS138.51 JF280046 T L. cucullatum CMW1141 JF280039 T -$]_{100}$

L. raffai CMW34451 MT637206 T

Fig. 5 (See legend on previous page.) 


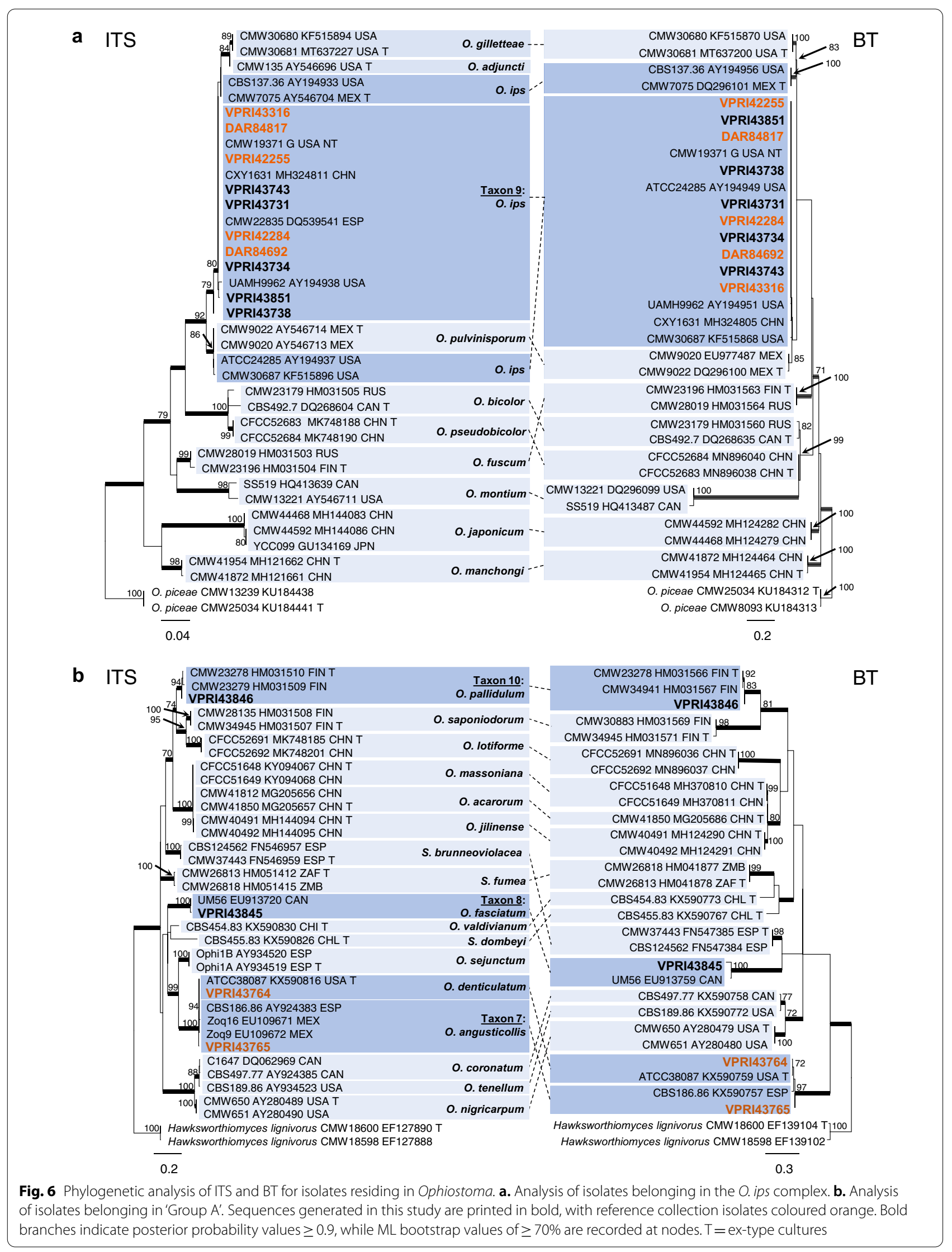



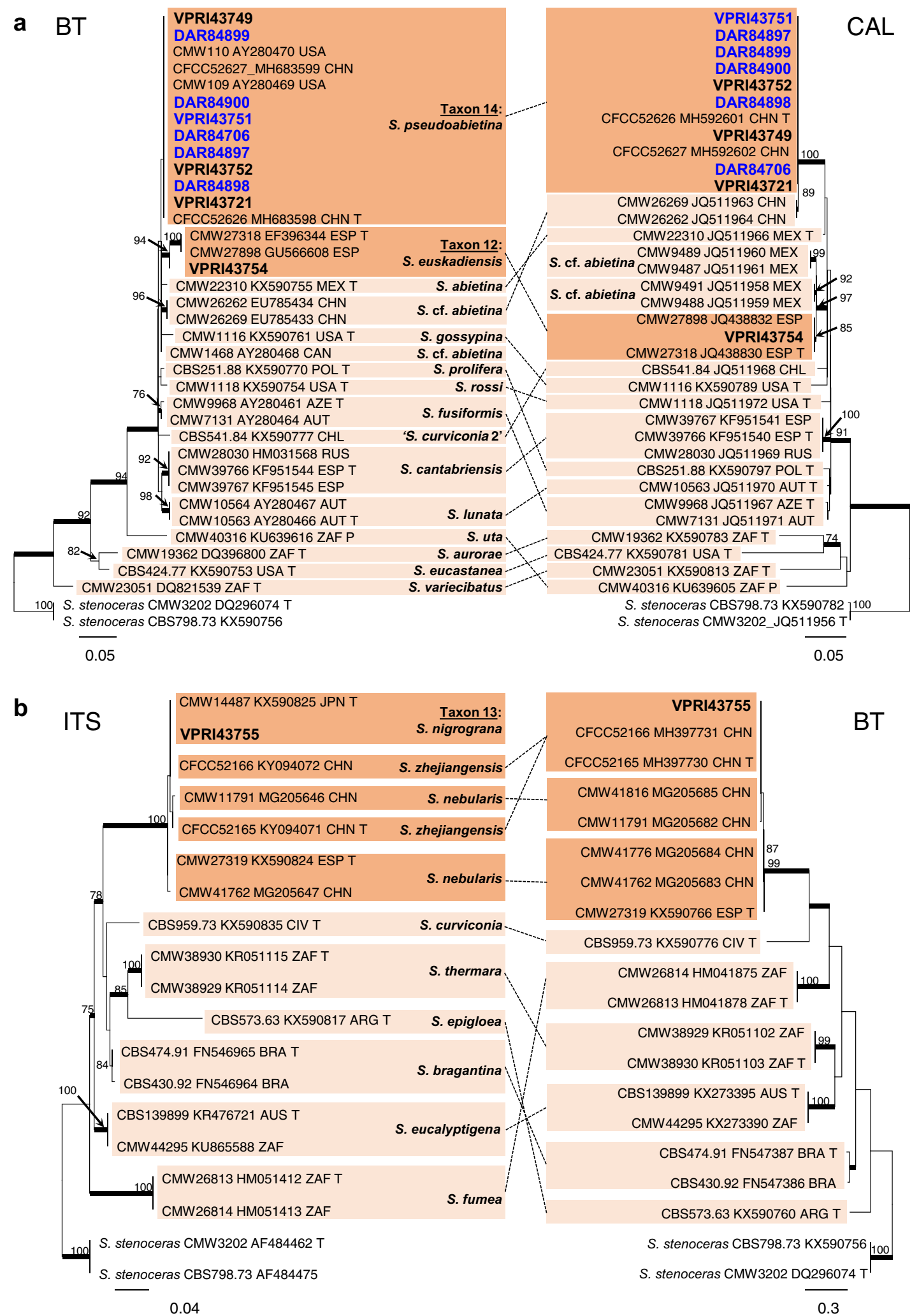

Fig. 7 Phylogenetic analysis of isolates residing in Sporothrix. a. Analysis of the BT and CAL regions for the S. gossypina complex. b. Analysis of the ITS and BT regions for Sporothrix 'Group G'. Sequences generated in this study are printed in bold, with reference collection isolates coloured blue. Bold branches indicate posterior probability values $\geq 0.9$. ML bootstrap values of $\geq 70 \%$ are recorded at nodes. $T=$ ex-type cultures 


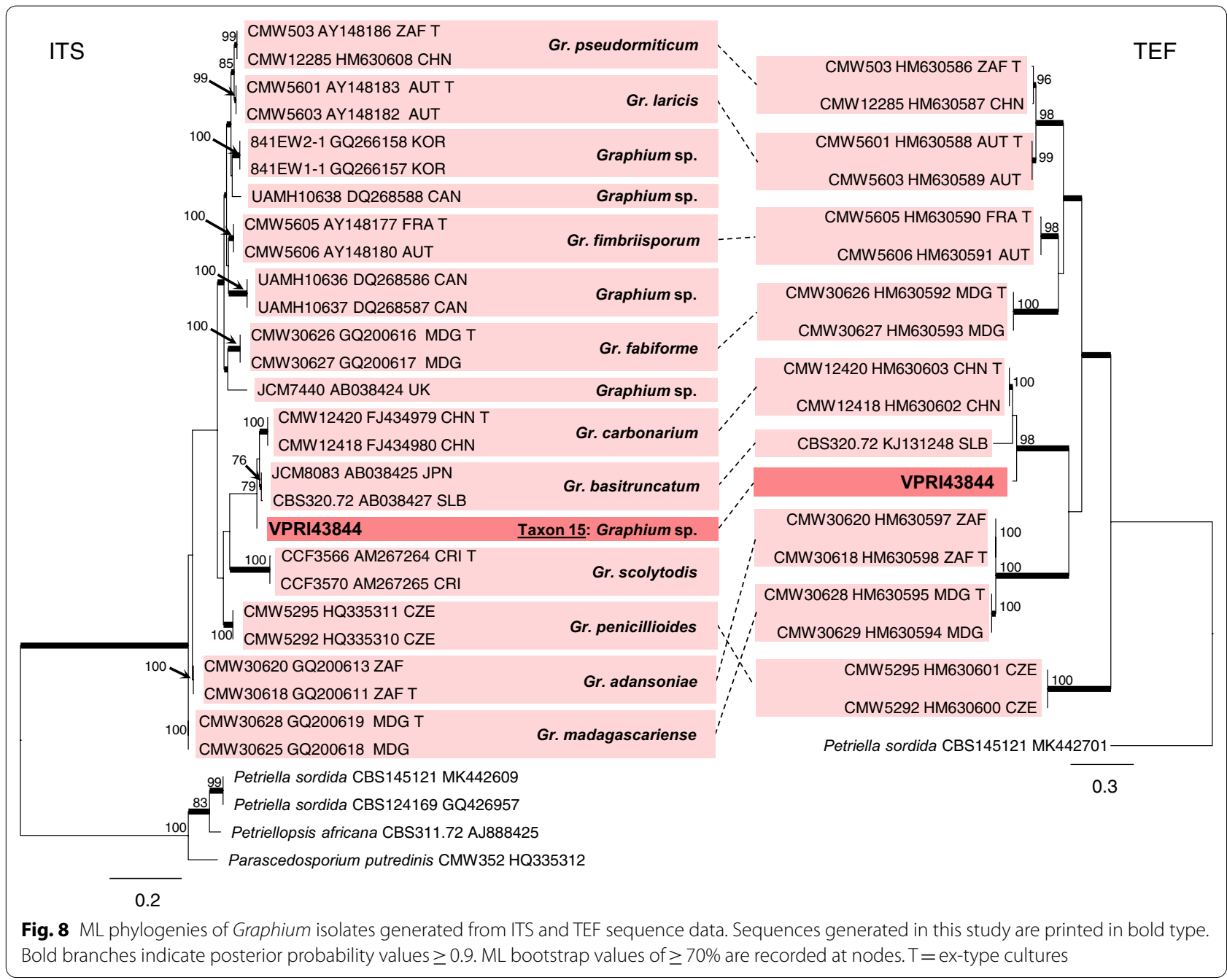

current study represent first records for Australia, molecular sequence data has verified the previous morphological records of a Ceratocystiopsis sp. (Stone and Simpson 1987) and a Graphium sp. (Vaartaja 1967). Notably however, five previous records still require molecular confirmation and their current status should be treated with care due to the numerous taxonomic re-evaluations that have taken place since their initial identification (Table 2; footnotes).

\section{Draft genomes of representative isolates} of ophiostomatoid fungi from Australian pine plantations Genome summary statistics of the representative draft genomes produced in this study are summarised in Table 3 (see Additional file 3: Table S3 for extended comparison). Genomes were assembled to an average size of $28 \mathrm{Mb}$ and were represented by a mean scaffold number of 148 . The N50 ranged from 208,570 to $1,285,428 \mathrm{bp}$, with the longest contig of 3,412,636 bp generated for the S. pseudoabietina strain, VPRI34531. The GC content had a mean of $57 \%$, with a standard deviation of $3 \%$ from this mean. Gene predictions resulted in an average estimate of 7800 Open Reading Frames (ORFs), with a gene density ranging from 240 to $341 \mathrm{ORFs} / \mathrm{Mb}$. All draft genomes had a high BUSCO completeness assessment score ranging between 93.48 and $98.24 \%$. All representative draft genomes were made publicly available on GenBank with Accession details summarised in Table 3.

\section{Taxonomy}

Graphilbum ipis-grandicollis C. Trollip, Q. Dinh, \& Jacqueline Edwards, sp. nov.

MycoBank: MB840696.

(Fig. 9)

Etymology: ipis-grandicollis (Latin), referring to Ips grandicollis, the bark beetle vector of this species.

Diagnosis: Graphilbum ipis-grandicollis is phylogenetically distinct from all morphologically similar species, 
Table 2 Current status list of Australian ophiostomatoid fungi associated with Pinus

\begin{tabular}{|c|c|c|c|c|c|}
\hline Genus & Species/taxon recorded & State/s & Verified & GenBank accession & References \\
\hline \multicolumn{6}{|l|}{ Ophiostomatales } \\
\hline \multirow[t]{2}{*}{ Ceratocystiopsis } & Ceratocystiopsis sp. ${ }^{a}$ & NSW & + & Table 1 & $\begin{array}{l}\text { Stone and Simpson (1987, 1990), Cur- } \\
\text { rent study }\end{array}$ \\
\hline & Ceratocystiopsis minuta & NSW & - & NA & Stone and Simpson (1990) \\
\hline \multirow[t]{4}{*}{ Graphilbum $^{b}$} & Pesotum aff. fragrans & SA & + & DQ062977 & $\begin{array}{l}\text { Harrington et al. (2001); Thwaites et al. } \\
\text { (2005) }\end{array}$ \\
\hline & Graphilbum fragrans & NSW & + & Table 1 & Carnegie et al. (2019), Current study \\
\hline & $\begin{array}{l}\text { Graphilbum ipis-grandicollis, sp. } \\
\text { nov. }\end{array}$ & NSW & + & Table 1 & Current study \\
\hline & Graphilbum cf. rectangulosporium & NSW & + & Table 1 & Current study \\
\hline \multirow[t]{7}{*}{ Ophiostoma } & Ophiostoma pilifera & $\mathrm{VIC}$ & - & & Eckersley (1934), Rawlings (1960) \\
\hline & Ophiostoma ips & NSW, QLD, SA, VIC & + & Table 1 & $\begin{array}{l}\text { Vaartaja 1967, Zhou et al. 2007, Carn- } \\
\text { egie et al. 2019, Current study }\end{array}$ \\
\hline & Ophiostoma floccosum & SA & - & NA & Harrington et al. (2001) \\
\hline & Ophiostoma quercus & SA & - & NA & Harrington et al. (2001) \\
\hline & Ophiostoma angusticollis & NSW & + & Table 1 & Carnegie et al. (2019), Current study \\
\hline & Ophiostoma pallidulum & NSW, TAS & + & Table 1 & Carnegie et al. (2019) Current study \\
\hline & Ophiostoma fasciatum & NSW & + & Table 1 & Current study \\
\hline \multirow[t]{3}{*}{ Leptographium s.l } & Grosmannia huntii & NSW, VIC, TAS & + & Table 1 & $\begin{array}{l}\text { Jacobs et al. (1998), Carnegie et al. } \\
\text { (2019), Current study }\end{array}$ \\
\hline & Leptographium sp..$^{c}$ & TAS & - & NA & Griggs, J.A. thesis (1998) \\
\hline & Grosmannia radiaticola & SA, TAS & + & Table 1 & Current study \\
\hline Raffaelea & Raffaelea deltoideospora & NSW & + & Table 1 & Current study \\
\hline \multirow[t]{3}{*}{ Sporothrix } & Sporothrix pseudoabietina & NSW, VIC & + & Table 1 & Carnegie et al. (2019), Current study \\
\hline & Sporothrix euskadiensis & NSW & + & Table 1 & Current study \\
\hline & Sporothrix cf. nigrograna & NSW & + & Table 1 & Current study \\
\hline \multicolumn{6}{|l|}{ Microascales } \\
\hline Graphium $^{d}$ & Graphium sp. & NSW & + & Table 1 & Vaartaja (1967) \\
\hline
\end{tabular}

Species identified in the current study are presented in bold, and their accession details can be found in Table 1

${ }^{a}$ We speculate that the taxon reported as Ceratocystiopsis sp. by Stone and Simpson $(1987,1990)$ is likely the same taxon recorded in the current study. Refer to discussion for more information

b Stone and Simpson (1990) reported a Graphilbum sp. associated with Ips grandicollis in NSW. This taxon could refer to any of the four taxa currently confirmed using molecular data

${ }^{c}$ Griggs, J.A. recorded Leptographium lundbergii in association with Hylastes ater infesting $P$. radiata in TAS. This ID has not been verified molecularly and should be treated with caution considering the taxonomic re-evaluation of $L$. lundbergii by Jacobs et al. (1998)

${ }^{d}$ Vaartaja (1967) identified several species of Graphium. This descriptor is somewhat ambiguous and could refer to species in both the Ophiostomatales and Microascales

from which it can be readily distinguished using molecular sequence data for the ITS, beta-tubulin, elongation factor 1-alpha, and calmodulin regions (Fig. 4, Additional file 4: Fig. S1).

Type: Australia: New South Wales: Moss Vale, Belanglo State Forest (Compartment 119), from Ips grandicollis gallery on Pinus radiata, 21 Aug. 2019, A. J. Carnegie (Holotype VPRI43762, stored in a metabolically inactive state; ex-holotype VPRI43762).

Description: Sexual morph not observed. Asexual morphs observed both synnematous and mononematous morphs. Synnematous morph: pesotum-like, macronematous, hyaline or pale yellow, erect, clavate, often singular, sometimes in groups, (102-)128-213(-263) $\mu \mathrm{m}$ long including conidiogenous apparatus, (14-)20-38(-45) $\mu \mathrm{m}$ wide at the base; conidiogenous cells (17-)19-26(-31) long; conidia hyaline, single-celled, smooth, cylindrical to oblong, (3-)4-6(-8) × (2-)2-3(-3) $\mu \mathrm{m}$. Mononematous morphs: hyalorhinocladiella-like, arising directly from mycelium; conidiophores, simple to strongly branched, hyaline, (27-)45-136(-170) $\mu \mathrm{m}$ long; conidiogenous cells (5-)13-27(-36) long; conidia hyaline, single-celled, smooth, oblong, often tapering at truncated base, (4-)4$8(-13) \times(2-) 2-3(-4) \mu \mathrm{m}$.

Culture characteristics: Colonies hyaline, circular with smooth growing edge on MEA. Mycelia submerged or 
Table 3 Genome summary statistics of representative ophiostomatoid isolates sequenced in this study

\begin{tabular}{|c|c|c|c|c|c|c|c|c|c|c|c|c|}
\hline \multirow[t]{2}{*}{ Species } & \multirow{2}{*}{\multicolumn{2}{|c|}{$\begin{array}{l}\text { Ceratocystiopsis } \\
\text { Ceratocystiopsis } \\
\text { sp. }\end{array}$}} & \multicolumn{6}{|l|}{ Graphilbum } & \multicolumn{3}{|c|}{ Leptographium s. I.. } & \multirow{2}{*}{$\begin{array}{l}\text { Ophiostoma s. I. } \\
\text { O. angusticollis }\end{array}$} \\
\hline & & & \multicolumn{2}{|l|}{ G. fragrans } & \multicolumn{2}{|c|}{$\begin{array}{l}\text { G. ipis- } \\
\text { grandicollis sp. } \\
\text { nov }\end{array}$} & \multicolumn{2}{|c|}{$\begin{array}{l}\text { G. cf. } \\
\text { rectangulosporium }\end{array}$} & \multicolumn{2}{|c|}{ Gro. huntii } & Gro. radiaticola & \\
\hline Taxon & Taxon 1 & & \multicolumn{2}{|l|}{ Taxon 2} & \multicolumn{2}{|l|}{ Taxon 3} & \multicolumn{2}{|l|}{ Taxon 4} & \multicolumn{2}{|c|}{ Taxon 5} & Taxon 6 & Taxon 7 \\
\hline Sequenced strain & in VPRI43766 & & \multicolumn{2}{|l|}{ VPRI43528 } & \multicolumn{2}{|l|}{ VPRI43762 } & \multicolumn{2}{|c|}{ VPRI43763 } & \multicolumn{2}{|c|}{ VPRI43530 } & VPRI43523 & VPRI43764 \\
\hline $\begin{array}{l}\text { GenBank Acces- } \\
\text { sion }\end{array}$ & \multicolumn{4}{|c|}{$\begin{array}{l}\text { JADHKF010000000JAD- } \\
\text { HKG010000000 }\end{array}$} & \multicolumn{2}{|c|}{$\begin{array}{l}\text { JAD- } \\
\text { HKH010000000 }\end{array}$} & \multicolumn{2}{|c|}{ JADHKI010000000 } & \multicolumn{3}{|c|}{$\begin{array}{l}\text { JADHKJ010000000JAD- } \\
\text { HKK010000000 }\end{array}$} & $\begin{array}{l}\text { JAD- } \\
\text { HKL010000000 }\end{array}$ \\
\hline $\begin{array}{l}\text { Total reads after } \\
\text { QC }\end{array}$ & $27,063,242$ & & \multicolumn{2}{|l|}{$50,135,289$} & \multicolumn{2}{|l|}{$49,429,518$} & $46,778,48$ & & 94,29 & 94,776 & $14,599,394$ & 10454088 \\
\hline $\begin{array}{l}\text { Number of scaf- } \\
\text { folds }\end{array}$ & 79 & & 237 & & 178 & & 117 & & 254 & 85 & 35 & 317 \\
\hline $\begin{array}{l}\text { Longest contig } \\
\text { (bp) }\end{array}$ & $1,540,000$ & & 999,956 & & $1,555,217$ & & $1,343,814$ & & 1,099 & 9,032 & $2,583,828$ & 651020 \\
\hline $\begin{array}{l}\text { Est. genome size } \\
(\mathrm{Mb})\end{array}$ & 20.45 & & 34.04 & & 24.02 & & 23.61 & & 28.05 & & 27.56 & 23.80 \\
\hline N50 (bp) & 471,680 & & 323,198 & & 601,306 & & 298,270 & & 343,8 & 842 & 383,760 & 236362 \\
\hline L50 & 12 & & 32 & & 13 & & 22 & & 25 & 11 & 1 & 34 \\
\hline \# N's per $100 \mathrm{kbp}$ & $p \quad 10$ & & 7 & & 14 & & 6 & & 8 & 5 & 1 & 14 \\
\hline GC (\%) & 61.48 & & 55.75 & & 55.53 & & 60.91 & & 54.63 & & 57.09 & 57.89 \\
\hline $\begin{array}{l}\text { Avg. coverage } \\
\text { depth }\end{array}$ & 197 & & 218 & & 305 & & 296 & & 493 & & 519 & 61 \\
\hline $\begin{array}{l}\text { No. of predicted } \\
\text { genes }\end{array}$ & 6967 & & 9034 & & 7221 & & 7270 & & 7836 & & 7867 & 8022 \\
\hline Est. gene density & y 341 & & 265 & & 301 & & 308 & & 279 & & 286 & 337 \\
\hline $\begin{array}{l}\text { Complete BUSCC } \\
(\%)\end{array}$ & O 95.20 & & 97.10 & & 95.60 & & 95.70 & & 97.40 & & 96.40 & 96.60 \\
\hline $\begin{array}{l}\text { Complete BUSCC } \\
\text { (n) }\end{array}$ & O 3636 & & 3706 & & 3647 & & 3651 & & 3716 & & 3680 & 3686 \\
\hline Complete-sing & gle 3631 & & 3699 & & 3644 & & 3648 & & 3710 & & 3673 & 3680 \\
\hline $\begin{array}{l}\text { Complete-dupl } \\
\text { cated }\end{array}$ & & & 7 & & 3 & & 3 & & 6 & 7 & 6 & 6 \\
\hline Fragmented & 17 & & 23 & & 29 & & 18 & & 17 & 21 & 21 & 18 \\
\hline Missing & 164 & & 88 & & 141 & & 148 & & 84 & & 16 & 113 \\
\hline Species & Ophiostoma s. & & & & & Raffo & elea & Sporothrix & & & & Graphium \\
\hline & O. fasciatum & O. $i$ & ips & O.p & allidulum & $\begin{array}{l}R . \\
\text { delto }\end{array}$ & ideospora & S. euskadier & ensis & $\begin{array}{l}\text { S. } \\
\text { cf. nigrograna }\end{array}$ & $\begin{array}{l}\text { S. } \\
\text { pseudoabietina }\end{array}$ & Graphium sp. \\
\hline Taxon & Taxon 8 & & xon 9 & Taxo & on 10 & Taxor & & Taxon 12 & & Taxon 13 & Taxon 14 & Taxon 15 \\
\hline $\begin{array}{l}\text { Sequenced } \\
\text { strain }\end{array}$ & VPRI43845 & & RI43529 & VPRI & 143846 & VPRIL & 3720 & VPRI43754 & & VPRI43755 & VPRI43531 & VPRI43844 \\
\hline $\begin{array}{l}\text { GenBank Acces- } \\
\text { sion }\end{array}$ & $\begin{array}{l}\text { JAD- } \\
\text { HKM010000000 }\end{array}$ & & $\begin{array}{l}\text { D- } \\
\text { KN010000000 }\end{array}$ & $\begin{array}{l}J A D \\
\text { HKO }\end{array}$ & 010000000 & $\begin{array}{l}\text { JAD- } \\
\text { HKPO }\end{array}$ & 10000000 & $\begin{array}{l}\text { JAD- } \\
\text { HKQ010000 }\end{array}$ & 0000 & $\begin{array}{l}\text { JAD- } \\
\text { HKR010000000 }\end{array}$ & $\begin{array}{l}\text { JAD- } \\
0 \text { HKS010000000 }\end{array}$ & $\begin{array}{l}\text { JAD- } \\
\text { HKT010000000 }\end{array}$ \\
\hline $\begin{array}{l}\text { Total reads after } \\
\text { QC }\end{array}$ & $51,287,508$ & & ,261,588 & 36,6 & 66,452 & 35,92 & 7,882 & $29,627,312$ & & $37,781,794$ & $36,719,768$ & $28,160,580$ \\
\hline $\begin{array}{l}\text { Number of scaf- } \\
\text { folds }\end{array}$ & 36 & 208 & & 473 & & 120 & & 92 & & 125 & 51 & 490 \\
\hline $\begin{array}{l}\text { Longest contig } \\
(\mathrm{Mb})\end{array}$ & $2,360,849$ & & 17,630 & 543 & 815 & 1,965 & 135 & $1,881,930$ & & $1,307,617$ & $3,412,636$ & $1,008,604$ \\
\hline $\begin{array}{l}\text { Est. genome size } \\
(\mathrm{Mb})\end{array}$ & 22.54 & 26. & .01 & 32.6 & & 30.95 & & 36.13 & & 27.34 & 35.20 & 31.65 \\
\hline N50 (bp) & 966,108 & & 3,044 & 126 & 120 & 416,3 & & 790,753 & & 398,989 & $1,285,428$ & 190,968 \\
\hline L50 & 9 & 29 & & 84 & & 25 & & 16 & & 23 & 9 & 49 \\
\hline $\begin{array}{l}\text { \# N's per } 100 \\
\text { kbp }\end{array}$ & 4 & 8 & & 12 & & 18 & & 11 & & 12 & 8 & 12 \\
\hline
\end{tabular}


Table 3 (continued)

\begin{tabular}{|c|c|c|c|c|c|c|c|c|}
\hline \multirow[t]{2}{*}{ Species } & \multicolumn{3}{|c|}{ Ophiostoma s. lat. } & \multirow{2}{*}{$\begin{array}{l}\text { Raffaelea } \\
R . \\
\text { deltoideospora }\end{array}$} & \multicolumn{3}{|l|}{ Sporothrix } & \multirow{2}{*}{$\begin{array}{l}\text { Graphium } \\
\text { Graphium sp. }\end{array}$} \\
\hline & O. fasciatum & O.ips & O. pallidulum & & S. euskadiensis & $\begin{array}{l}\text { S. } \\
\text { cf. nigrograna }\end{array}$ & $\begin{array}{l}\text { S. } \\
\text { pseudoabietina }\end{array}$ & \\
\hline GC (\%) & 65.26 & 56.88 & 57.93 & 54.55 & 52.70 & 59.54 & 53.27 & 50.12 \\
\hline $\begin{array}{l}\text { Avg. coverage } \\
\text { depth }\end{array}$ & 341 & 209 & 167 & 173 & 122 & 205 & 154 & 132 \\
\hline $\begin{array}{l}\text { No. of predicted } \\
\text { genes }\end{array}$ & 7498 & 7470 & 8757 & 7428 & 9348 & 7908 & 9190 & 9482 \\
\hline Est. gene density & y333 & 287 & 268 & 240 & 259 & 289 & 261 & 300 \\
\hline $\begin{array}{l}\text { Complete } \\
\text { BUSCO (\%) }\end{array}$ & 96.60 & 96.90 & 97.20 & 94.90 & 98.10 & 97.20 & 97.80 & 96.60 \\
\hline $\begin{array}{l}\text { Complete } \\
\text { BUSCO (n) }\end{array}$ & 3688 & 3696 & 3710 & 3621 & 3743 & 3710 & 3734 & 3686 \\
\hline $\begin{array}{l}\text { Complete- } \\
\text { single }\end{array}$ & 3685 & 3690 & 3705 & 3613 & 3739 & 3703 & 3729 & 3679 \\
\hline $\begin{array}{l}\text { Complete- } \\
\text { duplicated }\end{array}$ & 3 & 6 & 5 & 8 & 4 & 7 & 5 & 7 \\
\hline Fragmented & 16 & 16 & 28 & 30 & 10 & 23 & 12 & 40 \\
\hline Missing & 113 & 105 & 79 & 166 & 64 & 84 & 71 & 91 \\
\hline
\end{tabular}

flat on MEA and WA, with colonies reaching approx. $90 \mathrm{~mm}$ diam after 14, and $21 \mathrm{~d}$, respectively. Sporulation evident after one week of growth on pine needle amended WA. Initial formation of hyalorhinocladiellalike morphs submerged in agar, with sparse formation on the agar surface. This is followed by formation of the pesotum-like morphs, first forming on the pine needle between 7 and $14 \mathrm{~d}$, and eventually observed sparsely on the agar surface after 4-6 wk. Aerial hyphae bearing conidiophores, mycelial balls, and white to yellow synnemata-like clusters were also randomly observed on the two media.

Ecology: Isolated from beetles and beetle galleries found on various Pinus hosts. Host trees: Pinus radiata, P. elliottii and P. caribaea x elliottii hybrid (Additional file 2: Table S2). Insect vector: Ips grandicollis.

Distribution: Currently known only from New South Wales, Australia.

Notes: Graphilbum ipis-grandicollis forms part of an expanding species complex in Graphilbum, which includes G. crescericum, G. furuicola, G. interstitiale, G. kesiyae, and G. sexdentatum. Using morphology alone makes distinction between these closely related species difficult, as they share considerable similarities in the size and shapes of conidia, conidiogenous apparatus, and the asexual morphs recorded (Jankowiak et al. 2020).

Additional specimens examined: Australia: New South Wales: Moss Vale, Belanglo State Forest (Compartment 123), from I. grandicollis gallery on P. radiata, 21 Aug. 2019, A. J. Carnegie (VPRI43761 - culture);
Inverell, Copeton Dam, from Ips grandicollis gallery on P. radiata, 25 Jul. 2019, A. J. Carnegie (VPRI43759 culture); Tumut, Buccleuch State Forest (Compartment 1129), from $I$. grandicollis gallery on $P$. radiata, 2 Jun. 2019, D. Sargeant (VPRI43760 - culture).

\section{Discussion}

This study was undertaken to review and update the status of ophiostomatoid fungi associated with pine and pine bark beetles in plantations in south-eastern Australia. This was achieved by reviewing reference isolates available from historic collections lodged in Australian collections, as well as including a total of 120 new isolates collected through routine forest health surveillance during the 2019-20 period. Multi-locus phylogenetic analysis using whole genome sequencing of 46 representative isolates revealed a greater than expected diversity of ophiostomatoid fungi, including 14 species from six genera in Ophiostomatales and a single species residing in . While most species reported in this study were already known, our study includes seven first reports and three verifications for Australia, including the identification of three previously undescribed lineages, viz. Graphilbum ipis-grandicollis sp. nov. (Taxon 3), Ceratocystiopsis sp. (Taxon 1) and a Graphium sp. (Taxon 15). Draft genomes of representative isolates for each taxon are also provided here to contribute to a curated reference database of ophiostomatoid fungi for Australian biosecurity.

Of the five ophiostomatoid genera previously recorded from pine in Australia, isolates were available for Ophiostoma, Graphilbum, Leptographium s. lat., and Sporothrix. 


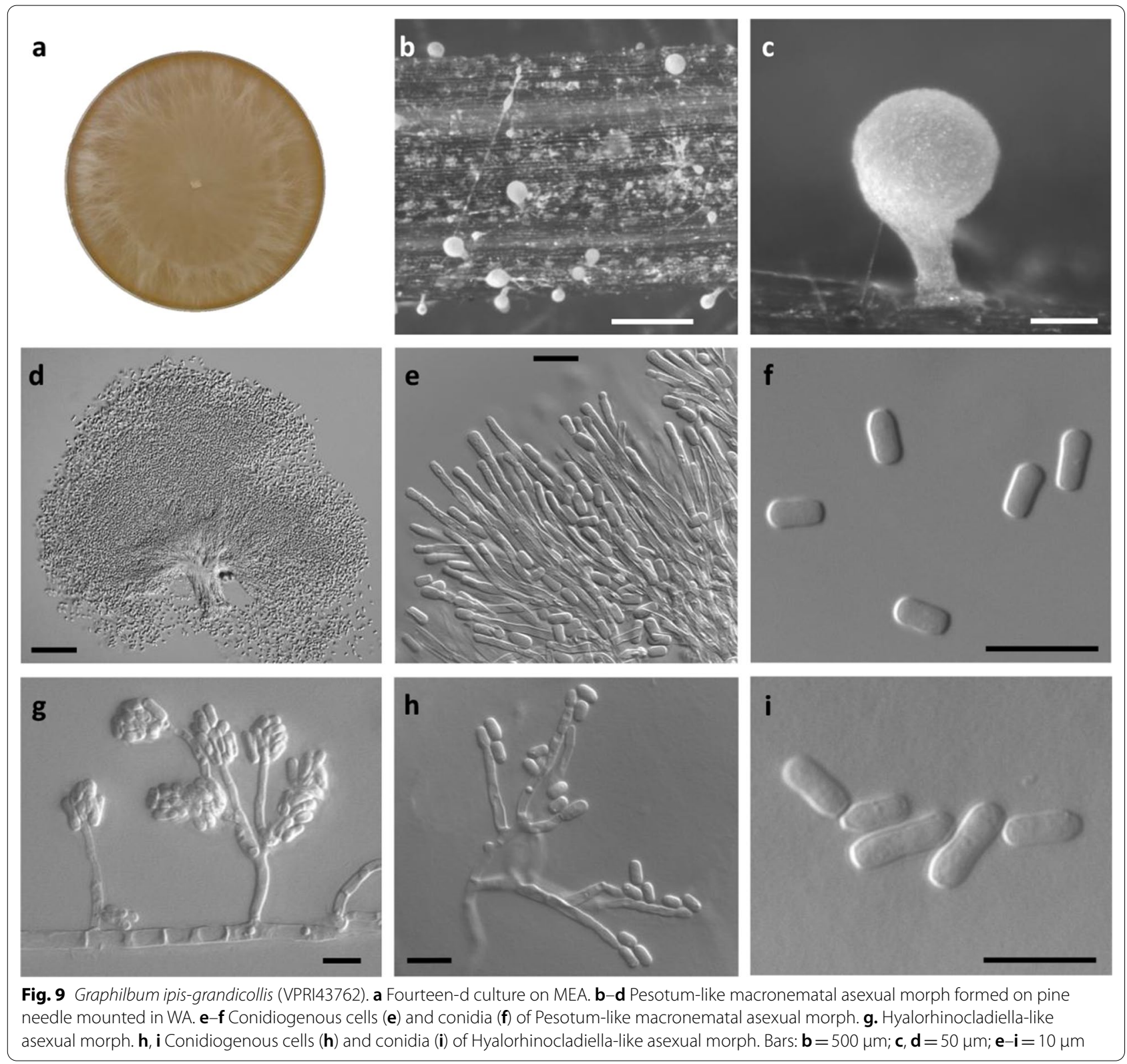

Results of the collection database searches allowed for the inclusion of reference isolates of G. fragrans (Taxon 2), Gro. huntii (Taxon 5), O. angusticollis (Taxon 7), O. ips (Taxon 9), and several initially identified as Sporothrix species (Carnegie and Nahrung 2019; Carnegie et al. 2019). Sporothrix isolates obtained from the Australian reference collections were putatively identified as $S$. $c f$. abietina or $O$. nigrocarpum based on BLAST results of the ITS during routine diagnostics (Carnegie et al. 2019). However, our results revealed that these isolates were all a single species, identified here as S. pseudoabietina. Although historical records also included the morphological identification of taxa belonging to Ceratocystiopsis (Stone and Simpson 1987, 1990), no reference material was available of this genus. Similarly, with the recent detection of O. pallidulum (Carnegie and Nahrung 2019; Carnegie et al. 2019), no isolates were readily available for inclusion in this study.

Detections made during the current survey included seven taxa not previously recorded in Australia. Four were identified as known species: specifically, Gro. radiaticola (Taxon 6), O. fasciatum (Taxon 8), $R$. deltoideospora (Taxon 11), and S. euskadiensis (Taxon 12). Taxon 4 and 13 are tentatively identified here as G. $c f$. 
rectangulosporium and $S$. cf. nigrograna, respectively. Both these taxa require further taxonomic revision due to a lack of available reference data in each case. The remaining first records included the detection of the novel species Graphilbum ipis-grandicollis sp. nov., as well as an undescribed lineage in Ceratocystiopsis and Graphium, respectively. For both, our record here serves as a first verification of presence made using molecular data. These new detections were considered in a biosecurity context, following guidelines in the Emergency Plant Pest Response Deed (Plant Health Australia EPPRD 2020; https://www.planthealthaustralia.com.au/wp-content/ uploads/2020/09/EPPRD-2-September-2020.pdf), and determined not to be significant pathogens nor feasible to eradicate.

Isolates of Ceratocystiopsis (Taxon 1) from this study grouped closely to the Cop. ranaculosa-brevicomis complex, with morphological and molecular sequence data suggesting that it is most closely related to a previously undescribed North American taxon, Ceratocystiopsis sp. 1 (Kim et al. 2005a, b; Lee et al. 2006; Plattner et al. 2009). As mentioned, previous reports of Ceratocystiopsis in Australia were based on morphology alone and included the putative identification of two taxa-one of which was recorded as Cop. minuta (Stone and Simpson 1987). A preceding study by the same authors, however, only referred to the Australian isolates in this taxon as Ceratocystiopsis sp. (Stone and Simpson 1990). Interestingly, the morphological descriptions made by those authors correlate with the morphological description of a Ceratocystiopsis sp. 1 identified in North America, which were described as Cop. minuta-like (Plattner et al. 2009). It is possible therefore to speculate that the isolates collected in this study represent this same taxon reported by Stone and Simpson. Most of the Ceratocystiopsis isolates collected in the current survey were isolated from I. grandicollis beetles collected from $P$. ponderosa, $P$. caribaea $\mathrm{x}$ elliottii and $P$. taeda in northern NSW, the same region that Stone and Simpson collected from.

The genus Graphilbum has recently been expanded to include 20 formally described species, which are characterised by synnematous pesotum-like and/or mononematous hyalorhinocladiella-like asexual morphs (Seifert et al. 2013; Jankowiak et al. 2020). Of the three Graphilbum taxa from Australian pine plantations, one was identified as G. fragrans (Taxon 2). G. fragrans can be considered the most common species of the genus and is known to have a global distribution, including reports from Europe, Asia, North and South America, as well as Australasia (Harrington et al. 2001; Thwaites et al. 2005; Seifert et al. 2013; Chang et al. 2017; Jankowiak et al. 2020). Previous studies have suggested that $G$. fragrans comprises potentially cryptic species, based on
Graphilbum isolates collected from New Zealand and Australia, which show differences in morphological comparisons and sequence analysis of the ITS (Harrington et al. 2001; Thwaites et al. 2005). The G. fragrans isolates collected in the present study shared high sequence similarity with the type strain CBS279.54 from Sweden and are clearly distinguishable from the single sequence available for the putative taxon reported as G. aff. fragrans from Australasia in 2005 (Harrington et al. 2001; Thwaites et al. 2005; De Beer and Wingfield 2013).

Graphilbum ipis-grandicollis sp. nov. (Taxon 3) grouped with several species residing in an evidently expanding complex of bark beetle associates isolated from Europe and China (Chang et al. 2017; Jankowiak et al. 2020). Multi-locus phylogenetic analysis suggests Taxon 3 is most closely related to a clade comprised of G. crescericum, G. furuicola, G. interstitiale, G. kesiyae, and G. sexdentatum. While ITS sequence data suggests a close relationship to a previously undescribed Graphilbum isolate from North America (GU129997; Fig. 4.) further investigations are required to postulate as to the true origin of this novel taxon. The species within this complex are mainly distinguishable using molecular sequence data, with only minor morphological differences observed in characteristic features such as conidia or the production of mononematous conidiophores observed for only a couple of species (Jankowiak et al. 2020). Isolates of the Graphilbum sp. (Taxon 4) shared an identical ITS sequence with Graphilbum isolates previously reported as G. $c f$. rectangulosporium in the USA (Kim et al. 2011). The US isolates were described as sterile and shown to share high levels of sequence similarity with the type strain of $G$. rectangulosporium from Japan (AB242825; Ohtaka et al. 2006; Kim et al. 2011). Cultures of the isolates in the current study did not produce either sexual or asexual characters, an observation that further validates the association with the US isolates. The lack of morphologically distinguishing characteristics in culture, as well as limited availability of alternative barcoding loci currently restricts further taxonomic placement, and so we refer to this taxon as G. cf. rectangulosporium.

In Leptographium s.lat., isolates of Grosmannia huntii (Taxon 5) and Gro. radiaticola (Taxon 6) were collected in this study. Gro. huntii was first reported in Australia in 1998, when it was believed to have been introduced along with its insect vector, $H$. ater (Jacobs et al. 1998). Until now, the known distribution within Australia included Victoria and NSW in association with $H$. ater and Hy. ligniperda. The isolations made in the current study expand the known distribution to include Tasmania, where it was isolated from stumps in recently harvested pine plantations infested by the root-feeding bark beetle, Hy. ligniperda. Taxon 6 included three isolates of 
Gro. radiaticola which were collected from $P$. radiata samples infested with $H$. ater in South Australia, and Hy. ligniperda in Tasmania. These are the first records of Gro. radiaticola for Australia. Gro. radiaticola forms part of the Gro. galeiformis species complex, and has been previously reported across Eurasia (Kim et al. 2005a, b; Linnakoski et al. 2012; Jankowiak and Bilański 2013a, b; Chang et al. 2017) and throughout the Southern Hemisphere, including South America, South Africa, and New Zealand (Zhou et al. 2001, 2006; Thwaites et al. 2013; de Errasti et al. 2018).

Of the four species in our study residing within Ophiostoma s. lat., only O. ips (Taxon 9) grouped in a wellrecognised species complex. The remaining three species, O. angusticollis (Taxon 7), O. fasciatum (Taxon 8) and O. pallidulum (Taxon 10), currently group within smaller lineages that sit peripherally to Ophiostoma s. str. and are commonly referred to as 'Group A' (Chang et al. 2017; Wang et al. 2020). Species residing in Group A are consistently recorded in low numbers and known to be highly phoretic (non-permanent interaction for the purpose of travel) in their association with insects (Chang et al. 2017). Ophiostoma fasciatum was first described in Canada in 1972 from Pseudotsuga menziesii (as Ceratocystis fasciata; Olchowecki and Reid 1974) and P. banksiana (as Ceratocystis spinifera; Olchowecki and Reid 1974). The single isolate of O. fasciatum (Taxon 8) collected in this survey came from I. grandicollis collected from a P. caribaea $\mathrm{x}$ elliottii hybrid in northern NSW and has not been previously reported in Australia. O. pallidulum and O. angusticollis species were recently detected in NSW in 2016 and 2017, respectively (Carnegie and Nahrung 2019). The single isolate of $O$. pallidulum from our current survey was collected from a Hy. ligniperda beetle sampled in Tasmania and serves as a first report outside of NSW.

The single isolate of Raffaelea deltoideospora (Taxon 11) was isolated directly from galleries of I. grandicollis found on a $P$. caribaea $x$ elliottii hybrid from northern NSW. $R$. deltoideospora was originally described from isolates collected from the wood of several pine species in Canada (Olchowecki and Reid 1974). Later records have found this species associated with cerambycid pupal chambers in the USA and China (Wingfield 1987; Wang et al. 2018). $R$. deltoideospora has also been reported from $P$. pinaster in the Iberian Peninsula (Villarreal et al. 2005). This is a first report for this fungus in Australia.

Results of our study revealed three species of Sporothrix present in Australian pine plantations. Two species belonged to the $S$. gossypina species complex, namely, $S$. pseudoabietina (Taxon 14) and S. euskadiensis (Taxon 12). Species within this complex are commonly isolated from bark beetle and mite associates (De Beer et al. 2016). Taxon 14 showed close association to several undescribed lineages previously referred to as either $S$. $c f$. abietina or Sporothrix sp., which included isolates from the USA, Mexico, South Africa, Poland and China (Zhou et al. 2004a; Min et al. 2009; Romón et al. 2014; Jankowiak et al. 2018). In 2019, this taxon was formally described as S. pseudoabietina, with the type specimen originating in China (Wang et al. 2019). Our results confirm that $S$. pseudoabietina is a commonly isolated fungus from Australian-grown pine which was first detected in 2019 (Carnegie et al. 2019). The second species belonging to this complex was identified as S. euskadiensis, associated with I. grandicollis. S. euskadiensis was first described from $P$. radiata in Spain, where isolates were associated with Hylurgops palliatus and Hylastes attenuatus (Romón et al. 2014).

The third species of Sporothrix identified during this study, Taxon 13, sits within species complex 'G' (De Beer et al. 2016). Molecular analysis and taxonomic placement for this isolate exemplifies some of the major challenges for diagnostics of ophiostomatoid fungi. Our single strain shared an identical ITS sequence with the type specimens of both S. nigrograna and S. zhejiangensis (De Beer et al. 2016; Wang et al. 2018). LSU sequences for our strain also shared high sequence similarity to those available for both S. nebularis and S. nigrograna (De Beer et al. 2016). The lack of available sequence data for other molecular regions of $S$. nigrograna limits further comparison to this species, and therefore analysis of the BT region was only possible for sequences from $S$. nebularis and $S$. zhejiangensis. Using BT alone would delimit our strain as $S$. zhejiangensis. Morphologically these species can only be distinguished by the presence or absence of a sheath on ascospores (Masuya et al. 2003; Wang et al. 2019). Until appropriate taxonomic comparison is possible, we refer to this isolate as $S$. $c f$. nigrograna due to its initial placement with $S$. nigrograna and its distinction from S. nebularis.

A single isolate (Taxon 15) residing within Graphium (Microascales) was collected from an I. grandicollis gallery originating from P. elliottii in NSW. ML analysis of our strain revealed a potentially distinct lineage that is closely related to Gra. basitruncatum and Gra. carbonarium. Gra. basitruncatum was first described from soil in the Solomon Islands (Okada et al. 2000), while Gra. carbonarium was isolated from Pissodes beetles on Salix babylonica in Yunnan, China (Paciura et al. 2010). With only this single isolate obtained we refer to this taxon as Graphium sp. until more isolates can be collected and studied.

Although the relationship of ophiostomatoid fungi and arthropod vectors has been extensively studied, the precise role of each taxonomic group within these systems and the specificity of these associations, are yet to be clearly defined (Chang et al. 2017; Wingfield et al. 2017b). All taxa isolated in the current study form part 
of species complexes and/or groupings that are consistently associated with bark beetles or other insect vectors (De Beer et al. 2016; Wingfield et al. 2017b). While our goal was to assess the diversity of ophiostomatoid fungi associated with pine bark beetles and beetle galleries collected during routine forest health surveillance, $I$. grandicollis was the more commonly encountered beetle species during the current surveillance period. This was a somewhat expected observation as, historically, I. grandicollis is more commonly caught in NSW than either H. ater or Hy. ligniperda (Stone et al. 2010). While this could explain the dominance observed for some of the ophiostomatoid species isolated, such as Ophiostoma ips and Sporothrix pseudoabietina, our results highlight the potential phoresy of these associations with I. grandicollis being linked to seven of the taxa recovered during this study (Additional file 2: Table S2). While we were able to make a few general observations regarding the patterns of isolations, a more in-depth systematic review would be required for an improved understanding and description of these fungus-vector associations across Australia. More targeted surveys, particularly studies focused on the insect vectors present, are likely to reveal an even greater diversity, for example, the isolates of Gro. radiaticola and Gro. huntii were only recovered from samples that came from $H$. ater and Hy. ligniperda infestations.

Genome assemblies for the isolates chosen as representatives for each taxon collected in this study resulted in the addition of $12 \mathrm{draft}$ genomes to the Ophiostomatales, and the release of the first draft genome publicly available for an isolate residing in the Graphiaceae (Microascales). The genome assembly statistics of the Ophiostomatales isolates collected during this study mirror those available for species residing in Ophiostoma, Sporothrix, Graphilbum, Leptographium s.l., Ceratocystiopsis and Raffaelea (DiGuistini et al. 2011; Forgetta et al. 2013; Haridas et al. 2013; Teixeira et al. 2014; van der Nest et al. 2014; Wingfield et al. 2015a, b, 2016, 2017a, 2018; D'Alessandro et al. 2016; Huang et al. 2016; Shang et al. 2016; Jeon et al. 2017; Vanderpool et al. 2018; Liu et al. 2019). Comparisons of genome statistics, specifically estimated size, GC content and number of predicted genes, generally correlate with the taxonomic placement of each species (Additional file 3: Table S3). This is evident, for example, when comparing the genomes of Gro. galeiformis and Gro. radiaticola, or S. euskadiensis and S. pseudoabietina. In both cases the size, GC content and number of predicted open reading frames (ORFs) vary marginally. There are however slight deviations evident within some genera. For example, in Ceratocystiopsis the genome sizes range from 20.45 to $21.30 \mathrm{Mb}$, and the number of predicted ORFs are somewhat lower for Cop. brevicomis (6884 ORFs) and
Ceratocystiopsis sp. VPRI43766 (Taxon 1; 6967 ORFs) when compared to that of Cop. minuta (7786 ORFs).

In the modern era, fungal taxonomy relies more heavily on an integrative approach where genealogical concordance is combined with morphological examination to recognise and delimit species (Lücking et al. 2020). For taxonomists and diagnosticians looking to delineate taxa of ophiostomatoid fungi, this could include analysing anything from two to ten different gene regions (De Beer and Wingfield 2013; De Beer et al. 2014, 2016) all while comparing morphological characters that can prove extremely difficult to distinguish (Jankowiak et al. 2020). Another major challenge that was exemplified several times in this study is the inconsistency of recovering sequence data for specific taxa. As the cost of sequencing continues to decrease, the feasibility for future taxonomic surveys to include whole genome sequences should become more readily attainable. As shown in this study, future taxonomic surveys could strive to include whole genome sequence data published alongside their identifications and/or descriptions of novel taxa. Currently, in the Ophiostomatales the number of available genomes encompasses 38 species across 11 genera. Expanding these genomic resources provides a fundamental platform on which diagnostic and biosecurity capacity can be developed.

\section{Conclusions}

The results of this study have uncovered a higher than expected diversity for ophiostomatoid fungi associated with pine and pine bark beetles in south eastern Australia. The current status of ophiostomatoid fungi in Australian pine plantations confirmed using molecular data has been expanded from 7 previously confirmed taxa to now include 15 verified species across six genera in the Ophiostomatales, as well as a single taxon identified in the Graphiaceae (Microascales). As demonstrated several times in this study, a major challenge for accurate fungal diagnostics and species delimitation is the availability of multi-locus sequence data for reference specimens. With the ever-decreasing costs of sequencing, as well as the need for multi-locus sequence data, our study provides an early example of WGS replacing standard PCR-based approaches. Future taxonomic studies could begin to look in earnest at the opportunities of providing the full complement of DNA sequence data along with the results of a given taxonomic survey. This would ensure that taxonomic studies continue to improve upon the availability of molecular data while rapidly expanding on the numbers of sampled taxa. Results of the current survey, coupled with other recent detections in Australia, illustrates the need for continued surveillance of ophiostomatoid fungi. This not only provides an important platform for recognising the underlying diversity of these fungi but 
allows for the establishment of an improved ophiostomatoid-specific database which will continue to develop the diagnostic capabilities for Australian biosecurity.

\begin{abstract}
Abbreviations
BI: Bayesian inference; BT: $\beta$-Tubulin; CAL: Calmodulin; DAR: The NSW Plant Pathology and Mycology Herbarium; ITS: The internal transcribed spacer; LSU: The large ribosomal subunit (28S); MEA: Malt extract agar; ML: Maximum likelihood; NCBI: National Center for Biotechnology Information; NSW: New South Wales; s.lat:: Sensu lato; s.str.: Sensu stricto; TEF: Translation elongation factor 1-a; VPRI: The Victorian Plant Pathology Herbarium; WA: Water agar; WGS: Whole genome sequencing.
\end{abstract}

\section{Supplementary Information}

The online version contains supplementary material available at https://doi. org/10.1186/s43008-021-00076-w.

Additional file 1. Table S1. Sampling information.

Additional file 2. Table S2. Host association and isolation frequencies of ophiostomatoid fungi obtained during this study.

Additional file 3. Table S3. Extended genome summaries of ophiostomatoid fungi which correspond with all genera obtained during current study.

Additional file 4. Figure S1. ML phylogeny of the CAL region for isolates residing in Graphilbum. Sequences generated in this study are printed in bold type with reference collection isolates coloured purple. Bold branches indicate posterior probability values $\geq 0.9$. ML bootstrap values of $\geq 70 \%$ are recorded at nodes. $T=$ ex-type isolates.

Additional file 5. Figure S2. ML phylogeny of ITS region for representative species of Leptographium, Raffaelea and Hawksworthiomyces. Sequences generated in this study are printed in bold type. Bold branches indicate posterior probability values $\geq 0.9$. ML bootstrap values of $\geq 70 \%$ are recorded at nodes. $T=$ ex-type isolates.

Additional file 6. Figure S3. ML phylogeny of CAL for isolates residing in Sporothrix. Sequences generated in this study are printed in bold type. Bold branches indicate posterior probability values $\geq 0.9$. ML bootstrap values of $\geq 70 \%$ are recorded at nodes. $T=$ ex-type isolates.

\section{Acknowledgements}

We would like to thank and acknowledge the following for their assistance across various aspects of this study. David Sargeant, Matthew Nagel, Rudi Hoffman, Karl Wotherspoon and Nita Ramsden for their efforts in field collections during the forest health surveillance period. The Crop Health Services diagnosticians at Agriculture Victoria, specifically Isabel Valenzuela-Gonzalez for her assistance in beetle identifications and Ramez Aldaoud and Soheir Salib for the technical assistance provided during sample reception and processing. Robyn Brett, Karren Cowan, Jordan Bailey and Roger Shivas for the review, provision and maintenance of isolates in the VPRI, DAR and BRIP. Tom May for his advice and guidance in determining the appropriate Latin nomenclature for the species described herein. The authors would also like to acknowledge the growers whose plantations samples were collected from: Forestry Corporation of NSW, HVP Plantations, OneFortyOne, and Sustainable Timber Tasmania.

\section{Authors' contributions}

$\mathrm{CT}, \mathrm{JE}, \mathrm{BR}$ and AJC conceived the idea of the study, and all authors contributed to the study design. CT performed isolations, sequencing and data analysis with assistance and advice from JK, QD, RM and JE. QD performed microscopy for the species description and edited the descriptions text. CT wrote the manuscript, with editing and revision by JE, BR and AJC to produce the final version. All authors read and approved the final manuscript.

\section{Funding}

This project has been funded through iMapPESTS. iMapPESTS is a research, development and extension (RD\&E) project supported by Hort Innovation, through funding from the Australian Government Department of Agriculture as part of its Rural R\&D for Profit Program, with funding from 16 partner organisations, including Grains Research \& Development Corporation, Sugar Research Australia, Cotton Research \& Development Corporation, Wine Australia, AgriFutures Australia, Forest and Wood Products Australia, and Agriculture Victoria. CT is supported through a La Trobe University Postgraduate Research Scholarship and a La Trobe University Full Fee Research Scholarship at La Trobe University, Victoria, Australia. Funding organisations had no role in the study design, data collection, analysis, and interpretation, or the writing of the manuscript.

\section{Availability of data and materials}

All data generated or analysed during this study is included in this published article [and its supplementary information files] and/or is available from the corresponding author upon reasonable request.

\section{Declarations}

Ethics approval and consent to participate

Not applicable.

\section{Adherence to national and international regulations}

Not applicable.

\section{Consent for publication}

Not applicable.

\section{Competing interests}

The authors declare that they have no competing interests.

\section{Author details}

${ }^{1}$ School of Applied Systems Biology, La Trobe University, Bundoora, VIC 3083, Australia. ${ }^{2}$ Department of Jobs, Precincts and Regions, Agriculture Victoria Research, AgriBio Centre, Bundoora, VIC 3083, Australia. ${ }^{3}$ Forest Science, NSW Department of Primary Industries - Forestry, Parramatta, NSW 2150, Australia. ${ }^{4}$ Department of Jobs, Precincts and Regions, Biosecurity and Agricultural Services, Agriculture Victoria, Cranbourne, VIC 3977, Australia.

Received: 25 October 2020 Accepted: 31 July 2021

Published online: 01 September 2021

\section{References}

Alamouti SM, Kim J, Breuil C (2006) A new Leptographium species associated with the northern spruce engraver, Ips perturbatus, in western Canada. Mycologia 98(1):149-160. https://doi.org/10.1080/15572536.2006. 11832722

Brasier CM, Webber JF (2019) Is there evidence for post-epidemic attenuation in the Dutch elm disease pathogen Ophiostoma novo-ulmi? Plant Pathol 68(5):921-929. https://doi.org/10.1111/ppa.13022

Bushnell B (2014) BBMap: a fast, accurate, splice-aware aligner. Lawrence Berkeley National Lab.(LBNL), Berkeley, CA (United States),

Carnegie AJ, Nahrung HF (2019) Post-border forest biosecurity in Australia: response to recent exotic detections, current surveillance and ongoing needs. Forests 10(4):336

Carnegie AJ, Cant RG, Eldridge RH (2008) Forest health surveillance in New South Wales, Australia. Aust for 71(3):164-176. https://doi.org/10.1080/ 00049158.2008 .10675031

Carnegie AJ, Lawson S, Wardlaw T, Cameron N, Venn T (2018) Benchmarking forest health surveillance and biosecurity activities for managing Australia's exotic forest pest and pathogen risks. Aust for 81(1):14-23

Carnegie AJ, Daniel R, Lidbetter F, Daley A, Laurence M, Nagel M, Sargeant D, Duong TA, Wingfield MJ (2019) Pathogenicity and new records of exotic blue stain fungi on Pinus in Australia. In: Abstracts of Australasian Plant Pathology Society conference 2019, Melbourne, 25-28 November 2019.

Chang R, Duong TA, Taerum SJ, Wingfield MJ, Zhou XD, De Beer ZW (2017) Ophiostomatoid fungi associated with conifer-infesting beetles and their phoretic mites in Yunnan, China. Mycokeys 28:19-64. https://doi. org/10.3897/mycokeys.28.21758 
Chang R, Duong TA, Taerum SJ, Wingfield MJ, Zhou XD, Yin M, De Beer ZW (2019) Ophiostomatoid fungi associated with the spruce bark beetle Ips typographus, including 11 new species from China. Persoonia 42:50-74. https://doi.org/10.3767/persoonia.2019.42.03

Chen S, Zhou Y, Chen Y, Gu J (2018) fastp: an ultra-fast all-in-one FASTQ preprocessor. Bioinformatics 34(17):i884-i890

D'Alessandro E, Giosa D, Huang L, Zhang J, Gao W, Brankovics B, Oliveira MME, Scordino F, Passo CL, Criseo G (2016) Draft genome sequence of the dimorphic fungus Sporothrix pallida, a nonpathogenic species belonging to Sporothrix, a genus containing agents of human and feline sporotrichosis. Genome Announce 4(2)

De Beer ZW, Wingfield MJ (2013) Emerging lineages in the Ophiostomatales. In: Seifert KA, De Beer ZW, Wingfield MJ (eds) The ophiostomatoid fungi: expanding frontiers. CBS biodiversity series, vol 12. CBS-KNAW Biodiversity Centre, Utrecht, The Netherlands, pp 21-46

De Beer ZW, Seifert KA, Wingfield MJ (2013) The ophiostomatoid fungi: their dual position in the Sordariomycetes. In: Seifert KA, De Beer ZW, Wingfield MJ (eds) The ophiostomatoid fungi: expanding frontiers. CBS Biodiversity Series, vol 12. CBS-KNAW Biodiversity Centre, Utrecht, The Netherlands, pp 1-19

De Beer ZW, Duong TA, Barnes I, Wingfield BD, Wingfield MJ (2014) Redefining Ceratocystis and allied genera. Stud Mycol 79:187-219. https://doi.org/ 10.1016/j.simyco.2014.10.001

De Beer ZW, Duong TA, Wingfield MJ (2016) The divorce of Sporothrix and Ophiostoma: solution to a problematic relationship. Stud Mycol 83:165-191. https://doi.org/10.1016/j.simyco.2016.07.001

de Errasti A, Pildain MB, Rajchenberg M, Stenlid J (2018) Ophiostomatoid fungi isolated from three different pine species in Argentinian Patagonia. For Pathol 48(1). https://doi.org/10.1111/efp.12393

DiGuistini S, Wang Y, Liao NY, Taylor G, Tanguay P, Feau N, Henrissat B, Chan SK, Hesse-Orce U, Alamouti SM (2011) Genome and transcriptome analyses of the mountain pine beetle-fungal symbiont Grosmannia clavigera, a lodgepole pine pathogen. Proc Natl Acad Sci 108(6):2504-2509

Duong TA, De Beer ZW, Wingfield BD, Wingfield MJ (2012) Phylogeny and taxonomy of species in the Grosmannia serpens complex. Mycologia 104(3):715-732

Eckersley AM (1934) Some sap-staining organisms of Pinus radiata D. Don in Victoria. Proc R Soc Victoria 46:179-194

Fisher MC, Henk DA, Briggs CJ, Brownstein JS, Madoff LC, MCCraw SL, Gurr SJ (2012) Emerging fungal threats to animal, plant and ecosystem health. Nature 484(7393):186-194. https://doi.org/10.1038/nature10947

Forgetta V, Leveque G, Dias J, Grove D, Lyons R Jr, Genik S, Wright C, Singh S, Peterson N, Zianni M (2013) Sequencing of the Dutch elm disease fungus genome using the Roche/454 GS-FLX Titanium System in a comparison of multiple genomics core facilities. JBT 24(1):39

Gardes M, Bruns TD (1993) ITS primers with enhanced specificity for basidiomycetes-application to the identification of mycorrhizae and rusts. Mol Ecol 2(2):113-118

Griggs JA (1998) Management of Hylastes ater (Coleoptera: Scolytidae) attacking Pinus radiata seedlings. PhD Thesis, University of Tasmania, Australia

Haridas S, Wang Y, Lim L, Alamouti SM, Jackman S, Docking R, Robertson G, Birol I, Bohlmann J, Breuil C (2013) The genome and transcriptome of the pine saprophyte Ophiostoma piceae, and a comparison with the bark beetle-associated pine pathogen Grosmannia clavigera. BMC Genom 14(1):373

Harrington TC, McNew D, Steimel J (2001) Phylogeny and taxonomy of the Ophiostoma piceae complex and the Dutch Elm Disease. Mycologia 93(1):111-136

Harrington TC, Fraedrich S, Aghayeva DN (2008) Raffaelea lauricola, a new ambrosia beetle symbiont and pathogen on the Lauracea. Mycotaxon 104:399-404

Hofstetter RW, Dinkins-Bookwalter J, Davis TS, Klepzig KD (2015) Symbiotic associations of bark beetles. In: Vega FE, Hofstetter RW (eds) Bark beetles: biology and ecology of native and invasive species. Academic Press, New York, pp 209-246

Hood I, Ramsden M (1997) Sapstain and decay following fire in stands of Pinus elliottii var. elliottii near Beerburrum, south east Queensland. Aust For 60(1):7-15

Huang L, Gao W, Giosa D, Criseo G, Zhang J, He T, Huang X, Sun J, Sun Y, Huang $\mathrm{J}(2016)$ Whole-genome sequencing and in silico analysis of two strains of Sporothrix globosa. Genome Biol Evol 8(11):3292-3296
Huelsenbeck JP, Ronquist F (2001) MRBAYES: Bayesian inference of phylogenetic trees. Bioinformatics 17(8):754-755

Hyde KD, Norphanphoun C, Maharachchikumbura SSN, Bhat DJ, Jones EBG, Bundhun D, Chen YJ, Bao DF, Boonmee S, Calabon MS, Chaiwan N, Chethana KWT, Dai DQ, Dayarathne MC, Devadatha B, Dissanayake AJ, Dissanayake LS, Doilom M, Dong W, Fan XL, Goonasekara ID, Hongsanan S, Huang SK, Jayawardena RS, Jeewon R, Karunarathna A, Konta S, Kumar V, Lin CG, Liu JK, Liu NG, Luangsa-ard J, Lumyong S, Luo ZL, Marasinghe DS, McKenzie EHC, Niego AGT, Niranjan M, Perera RH, Phukhamsakda C, Rathnayaka AR, Samarakoon MC, Samarakoon SMBC, Sarma VV, Senanayake IC, Shang QJ, Stadler M, Tibpromma S, Wanasinghe DN, Wei DP, Wijayawardene NN, Xiao YP, Yang J, Zeng XY, Zhang SN, Xiang MM (2020) Refined families of sordariomycetes. Mycosphere 11(1):305-1059. https://doi.org/10.5943/mycosphere/11/1/7

Jacobs K, Wingfield MJ, Wingfield BD, Yamaoka Y (1998) Comparison of Ophiostoma huntii and $O$. europhioides and description of $O$. aenigmaticum sp. nov. Mycol Res 102(3):289-294

Jankowiak R (2012) Ophiostomatoid fungi associated with Ips sexdentatus on Pinus sylvestris in Poland. Dendrobiology 68:43-54

Jankowiak R, Bilański P (2013a) Diversity of ophiostomatoid fungi associated with the large pine weevil, Hylobius abietis, and infested Scots pine seedlings in Poland. Ann for Sci 70:391-402. https://doi.org/10.1007/ s13595-013-0266-z

Jankowiak R, Bilański P (2013b) Ophiostomatoid fungi associated with rootfeeding bark beetles on Scots pine in Poland. For Pathol 43:422-428. https://doi.org/10.1111/efp.12049

Jankowiak R, Bilański P, Chyrzyński Ł, Strzałka B (2018) Identification of sapstain fungi from Scots pine pallets and assessment of their staining ability. Eur J Plant Pathol 150(2):307-322. https://doi.org/10.1007/ s10658-017-1279-5

Jankowiak R, Solheim H, Bilanski P, Marincowitz S, Wingfield MJ (2020) Seven new species of Graphilbum from conifers in Norway, Poland, and Russia. Mycologia 1-23. https://doi.org/10.1080/00275514.2020.1778375

Jankowiak R, Szewczyk G, Bilański P, Jazłowiecka D, Harabin B, Linnakoski R. (2021) Blue-stain fungi isolated from freshly felled Scots pine logs in Poland, including Leptographium sosnaicola sp. nov. For Pathol 51:e12672. https://doi.org/10.1111/efp.12672

Jeon J, Kim K-T, Song H, Lee G-W, Cheong K, Kim H, Choi G, Lee Y-H, Stewart JE, Klopfenstein NB (2017) Draft genome sequence of the fungus associated with oak wilt mortality in South Korea, Raffaelea quercusmongolicae KACC44405. Genome Announce 5(34)

Katoh K, Rozewicki J, Yamada KD (2019) MAFFT online service: multiple sequence alignment, interactive sequence choice and visualization. Brief Bioinform 20(4):1160-1166

Kim JJ, Allen EA, Humble LM, Breuil C (2005a) Ophiostomatoid and basidiomycetous fungi associated with green, red, and grey lodgepole pines after mountain pine beetle (Dendroctonus ponderosae) infestation. Can J for Res 35(2):274-284

Kim JJ, Lim YW, Seifert KA, Kim SH, Breuil C, Kim GH (2005b) Taxonomy of Ophiostoma radiaticola sp. nov. (Ophiostomatales, Ascomycetes), the teleomorph of Pesotum pini, isolated from logs of Pinus radiata. Mycotaxon 91:481-496

Kim S, Harrington TC, Lee JC, Seybold SJ (2011) Leptographium tereforme sp. nov. and other Ophiostomatales isolated from the root-feeding bark beetle Hylurgus ligniperda in California. Mycologia 103(1):152-163. https://doi.org/10.3852/10-096

Kirisits T (2004) Fungal associates of European bark beetles with special emphasis on the ophiostomatoid fungi. In: Lieutier F, Day KR, Battisti A, Grégoire J, Evans HF (eds) Bark and wood boring insects in living trees in Europe, a synthesis. Springer, Amsterdam, pp 181-236

Kirisits T, Konrad H, Wingfield MJ, Chhetri D (2013) Ophiostomatoid fungi associated with the Eastern Himalayan spruce bark beetle, Ips schmutzenhoferi, in Bhutan and their pathogenicity to Picea spinulosa and Pinus wallichiana. In: Seifert KA, De Beer ZW, Wingfield MJ (eds) The ophiostomatoid fungi: expanding frontiers. CBS Biodiversity Series, vol 12. CBS-KNAW Biodiversity Centre, Utrecht, The Netherlands, pp 99-112

Klepzig KD, Hofstetter RW (2011) From attack to emergence: interactions between southern pine beetle, mites, microbes, and trees. In: Coulson RN, Klepzig KD (eds) Southern Pine Beetle II, vol 140. Department of Agriculture Forest Service, United States, pp 141-152 
Lee S, Kim J, Breuil C (2006) Diversity of fungi associated with the mountain pine beetle, Dendroctonus ponderosae and infested lodgepole pines in British Columbia. Fungal Diversity

Lefort V, Longueville J-E, Gascuel O (2017) SMS: smart model selection in PhyML. Mol Biol Evol 34(9):2422-2424

Linnakoski R, De Beer ZW, Duong TA, Niemela P, Pappinen A, Wingfield MJ (2012) Grosmannia and Leptographium spp. associated with coniferinfesting bark beetles in Finland and Russia, including Leptographium taigense sp. nov. Antonie Van Leeuwenhoek 102(2):375-399. https://doi. org/10.1007/s10482-012-9747-6

Liu F, Chen S, Ferreira MA, Chang R, Sayari M, Kanzi AM, Wingfield BD, Wingfield MJ, Pizarro D, Crespo A (2019) Draft genome sequences of five Calonectria species from Eucalyptus plantations in China, Celoporthe dispersa, Sporothrix phasma and Alectoria sarmentosa. IMA Fungus 10(1):1-13

Lücking R, Aime MC, Robbertse B, Miller AN, Ariyawansa HA, Aoki T, Cardinali G, Crous PW, Druzhinina IS, Geiser DM (2020) Unambiguous identification of fungi: where do we stand and how accurate and precise is fungal DNA barcoding? IMA Fungus 11(1):1-32

Marincowitz S, Duong TA, Taerum SJ, De Beer ZW, Wingfield MJ (2020) Fungal associates of an invasive pine-infesting bark beetle, Dendroctonus valens, including seven new Ophiostomatalean fungi. Persoonia Mol Phylogeny Evol Fungi 45:177-195. https://doi.org/10.3767/persoonia. 2020.45.07

Masuya H, Kaneko S, Yamaoka Y (2003) Three new Ophiostoma species isolated from Japanese red pine. Mycoscience 44(4):301-310. https://doi.org/10. 1007/s10267-003-0118-z

Masuya H, Yamaoka Y, Wingfield MJ (2013) Ophiostomatoid fungi and their associations with bark beetles in Japan. In: Seifert KA, De Beer ZW, Wingfield MJ (eds) The ophiostomatoid fungi: expanding frontiers. CBS Biodiversity Series, vol 12. CBS-KNAW Biodiversity Centre, Utrecht, The Netherlands, pp 77-89

Mikheenko A, Prjibelski A, Saveliev V, Antipov D, Gurevich A (2018) Versatile genome assembly evaluation with QUAST-LG. Bioinformatics 34:i142-i150

Min L, Zhou XD, De Beer ZW, Wingfield MJ, Sun J-H (2009) Ophiostomatoid fungi associated with the invasive pine-infesting bark beetle, Dendroctonus valens, in China. Fungal Divers 38:133-145

Nahrung HF, Loch AD, Matsuki M (2016) Invasive insects in Mediterranean forest systems: Australia. In: Paine TD, Lieutier F (eds) Insects and diseases of Mediterranean forest systems. Springer, Cham, pp 475-498

Nurk S, Bankevich A, Antipov D, Gurevich A, Korobeynikov A, Lapidus A, Prjibelsky A, Pyshkin A, Sirotkin A, Sirotkin Y (2013) Assembling genomes and mini-metagenomes from highly chimeric reads. In: Annual international conference on research in computational molecular biology. Springer, pp 158-170

Ohtaka N, Masuya H, Yamaoka Y, Kaneko S (2006) Two new Ophiostoma species lacking conidial states isolated from bark beetles and bark beetleinfested Abies species in Japan. Botany 84(2):282-293

Okada G, Jacobs K, Kirisits T, Louis-Seize G, Seifert K, Sugita T, Takematsu A, Wingfield M (2000) Epitypification of Graphium penicillioides Corda, with comments on the phylogeny and taxonomy of graphium-like synnematous fungi. Stud Mycol 45:169-186

Olchowecki A, Reid J (1974) Taxonomy of the genus Ceratocystis in Manitoba. Can J Bot 52(7):1675-1711

Paciura D, Zhou XD, De Beer ZW, Jacobs K, Ye H, Wingfield M (2010) Characterisation of synnematous bark beetle-associated fungi from China, including Graphium carbonarium sp. nov. Fungal Divers 40(1):75-88

Phillips CL (2008) Forest health surveillance in South Australia. Aust for 71 (3):196-201. https://doi.org/10.1080/00049158.2008.10675035

Plattner A, Kim JJ, Reid J, Hausner G, Lim YW, Yamaoka Y, Breuil C (2009) Resolving taxonomic and phylogenetic incongruence within species Ceratocystiopsis minuta. Mycologia 101(6):878-887. https://doi.org/10. 3852/08-132

Rawlings, GB (1960) Fungi associated with Pinus radiata. In: Scott, CW (ed) Pinus radiata. FAO Forest and Forest Products Studies no.14, pp 250-320

Romón P, De Beer ZW, Zhou XD, Duong TA, Wingfield BD, Wingfield MJ (2014) Multigene phylogenies of Ophiostomataceae associated with Monterey pine bark beetles in Spain reveal three new fungal species. Mycologia 106(1):119-132. https://doi.org/10.3852/13-073
Roux J, Heath R, Labuschagne L, Nkuekam GK, Wingfield M (2007) Occurrence of the wattle wilt pathogen, Ceratocystis albifundus on native South African trees. For Pathol 37(5):292-302

Santini A, Faccoli M (2015) Dutch elm disease and elm bark beetles: a century of association. iForest Biogeosci For 8(2):126

Seifert KA, De Beer ZW, Wingfield MJ (2013) The ophiostomatoid fungi: expanding frontiers. CBS biodiversity series, vol 12. CBS-KNAW Biodiversity Centre, Utrecht, The Netherlands

Shang Y, Xiao G, Zheng P, Cen K, Zhan S, Wang C (2016) Divergent and convergent evolution of fungal pathogenicity. Genome Biol Evol 8(5):1374-1387

Smith D, Smith I, Collett N, Elms S (2008) Forest health surveillance in Victoria. Aust for 71(3):188-195. https://doi.org/10.1080/00049158.2008.10675 034

Stamatakis A (2014) RAxML version 8: a tool for phylogenetic analysis and post-analysis of large phylogenies. Bioinformatics 30(9):1312-1313

Stone C, Simpson JA (1987) Influence of Ips grandicollis on the incidence and spread of blue stain fungi in Pinus elliottii billets in north-eastern New South Wales. Aust for 50(2):86-94. https://doi.org/10.1080/00049158. 1987.10674500

Stone C, Simpson JA (1990) Species associations in Ips grandicollis galleries in Pinus taeda. NZ J for Sci 20(1):75-96

Stone C, Goodyer G, Sims K, Penman T, Carnegie A (2010) Beetle assemblages captured using static panel traps within New South Wales pine plantations. Aust J Entomol 49:304-316

Taerum SJ, Duong TA, De Beer ZW, Gillette N, Sun JH, Owen DR, Wingfield MJ (2013) Large shift in symbiont assemblage in the invasive red turpentine beetle. PLoS ONE 8(10):e78126. https://doi.org/10.1371/journal. pone.0078126

Teixeira MM, de Almeida LG, Kubitschek-Barreira P, Alves FL, Kioshima ES, Abadio AK, Fernandes L, Derengowski LS, Ferreira KS, Souza RC (2014) Comparative genomics of the major fungal agents of human and animal Sporotrichosis: Sporothrix schenckii and Sporothrix brasiliensis. BMC Genom 15(1):1-22

Thwaites JM, Farrell RL, Duncan SM, Reay SD, Blanchette RA, Hadar E, Hadar Y, Harrington TC, McNew D (2005) Survey of potential sapstain fungi on Pinus radiata in New Zealand. NZ J Bot 43(3):653-663. https://doi.org/ $10.1080 / 0028825 \times .2005 .9512982$

Thwaites JM, Reay SD, Schirp A, Grinter W, Farrell RL (2013) Ophiostomatoid fungi and blue-stain in New Zealand. In: Seifert KA, De Beer ZW, Wingfield MJ (eds) The ophiostomatoid fungi: expanding frontiers. CBS Biodiversity Series, vol 12. CBS-KNAW Biodiversity Centre, Utrecht, The Netherlands, pp 113-118

Tsopelas P, Santini A, Wingfield MJ, De Beer ZW (2017) Canker stain: a lethal disease destroying iconic plane trees. Plant Dis 101(5):645-658

Vaartaja O (1967) The common fungal associates of the bark beetle, Ips grandicollis in Pinus radiata in South Australia. Aust for Res 2(4):40-43

van der Nest MA, Beirn LA, Crouch JA, Demers JE, De Beer ZW, De Vos L, Gordon TR, Moncalvo J-M, Naidoo K, Sanchez-Ramirez S (2014) Draft genomes of Amanita jacksonii, Ceratocystis albifundus, Fusarium circinatum, Huntiella omanensis, Leptographium procerum, Rutstroemia sydowiana, and Sclerotinia echinophila. IMA Fungus 5(2):472-486

Vanderpool D, Bracewell RR, McCutcheon JP (2018) Know your farmer: ancient origins and multiple independent domestications of ambrosia beetle fungal cultivars. Mol Ecol 27(8):2077-2094

Villarreal M, Rubio V, De Troya MT, Arenal F (2005) A new Ophiostoma species isolated from Pinus pinaster in the Iberian Peninsula. Mycotaxon 92:259-268

Walsh PS, Metzger DA, Higuchi R (1991) Chelex 100 as a medium for simple extraction of DNA for PCR-based typing from forensic material. Biotechniques 10(4):506-513

Wang H, Lun Y, Lu Q, Liu H, Decock C, Zhang X (2018) Ophiostomatoid fungi associated with pines infected by Bursaphelenchus xylophilus and Monochamus alternatus in China, including three new species. MycoKeys 39:1-27. https://doi.org/10.3897/mycokeys.39.27014

Wang H, Wang Z, Liu F, Xu WuC, Fang Zhang S, Kong XB, Decock C, Lu Q, Zhang Z (2019) Differential patterns of ophiostomatoid fungal communities associated with three sympatric Tomicus species infesting pines in south-western China, with a description of four new species. MycoKeys 50:93-133. https://doi.org/10.3897/mycokeys.50.32653 
Wang Z, Liu Y, Wang H, Meng X, Liu X, Decock C, Zhang X, Lu Q (2020) Ophiostomatoid fungi associated with Ips subelongatus, including eight new species from northeastern China. IMA Fungus 11:3. https://doi.org/10. 1186/s43008-019-0025-3

White TJ, Bruns T, Lee S, Taylor J (1990) Amplification and direct sequencing of fungal ribosomal RNA genes for phylogenetics. PCR Protoc 18(1):315-322

Wingfield MJ (1987) Fungi Associated with the Pine Wood Nematode, Bursaphelenchus xylophilus, and Cerambycid Beetles in Wisconsin. Mycologia 79(2):325-328

Wingfield MJ, Seifert KA, Webber JF (1993) Ceratocystis and Ophiostoma: taxonomy, ecology, and pathogenicity. American Phytopathological Society, St. Paul

Wingfield BD, Ades PK, Al-Naemi FA, Beirn LA, Bihon W, Crouch JA, De Beer ZW, De Vos L, Duong TA, Fields CJ (2015a) Draft genome sequences of Chrysoporthe austroafricana, Diplodia scrobiculata, Fusarium nygamai, Leptographium lundbergii, Limonomyces culmigenus, Stagonosporopsis tanaceti, and Thielaviopsis punctulata. IMA Fungus 6(1):233-248

Wingfield BD, Barnes I, De Beer ZW, De Vos L, Duong TA, Kanzi AM, Naidoo K, Nguyen HD, Santana QC, Sayari M (2015b) Draft genome sequences of Ceratocystis eucalypticola, Chrysoporthe cubensis, C. deuterocubensis, Davidsoniella virescens, Fusarium temperatum, Graphilbum fragrans, Penicillium nordicum, and Thielaviopsis musarum. IMA Fungus 6(2):493

Wingfield BD, Ambler JM, Coetzee MP, De Beer ZW, Duong TA, Joubert F, Hammerbacher A, McTaggart AR, Naidoo K, Nguyen HD (2016) IMA genome-F 6. IMA Fungus 7(1):217-227

Wingfield BD, Berger DK, Steenkamp ET, Lim H-J, Duong TA, Bluhm BH, De Beer ZW, De Vos L, Fourie G, Naidoo K (2017a) Draft genome of Cercospora zeina, Fusarium pininemorale, Hawksworthiomyces lignivorus, Huntiella decipiens and Ophiostoma ips. IMA Fungus 8(2):385-396

Wingfield MJ, Barnes I, De Beer ZW, Roux J, Wingfield BD, Taerum SJ (2017b) Novel associations between ophiostomatoid fungi, insects and tree hosts: current status-future prospects. Biol Invasions 19(11):32153228. https://doi.org/10.1007/s10530-017-1468-3

Wingfield BD, Liu M, Nguyen HD, Lane FA, Morgan SW, De Vos L, Wilken PM, Duong TA, Aylward J, Coetzee MP (2018) Nine draft genome sequences of Claviceps purpurea s. lat., including C. arundinis, C. humidiphila, and C. cf. spartinae, pseudomolecules for the pitch canker pathogen Fusarium circinatum, draft genome of Davidsoniella eucalypti, Grosmannia galeiformis, Quambalaria eucalypti, and Teratosphaeria destructans. IMA Fungus 9(2):401-418

Wotherspoon KP (2008) Forest health surveillance in Tasmania. Aust for 71(3):182-187. https://doi.org/10.1080/00049158.2008.10675033

Zhou XD, De Beer ZW, Wingfield BD, Wingfield MJ (2001) Ophiostomatoid fungi associated with three pine-infesting bark beetles in South Africa. SYDOWIA-HORN- 53(2):290-300

Zhou XD, De Beer ZW, Cibrian D, Wingfield BD, Wingfield MJ (2004a) Characterisation of Ophiostoma species associated with pine bark beetles from Mexico, including O. pulvinisporum sp. nov. Mycol Res 108(Pt 6):690-698. https://doi.org/10.1017/s0953756204009918

Zhou XD, De Beer ZW, Ahumada R, Wingfield BD, Wingfield MJ (2004b) Ophiostoma and Ceratocystiopsis spp. associated with two pine-infesting bark beetles in Chile. Fungal Divers 15:261-274

Zhou XD, De Beer ZW, Wingfield MJ (2006) DNA sequence comparisons of Ophiostoma spp., including Ophiostoma aurorae sp. nov., associated with pine bark beetles in South Africa. Stud Mycol 55:269-277. https:// doi.org/10.3114/sim.55.1.269

Zhou XD, Burgess TI, De Beer ZW, Lieutier F, Yart A, Klepzig K, Carnegie A, Portales JM, Wingfield BD, Wingfield MJ (2007) High intercontinental migration rates and population admixture in the sapstain fungus Ophiostoma ips. Mol Ecol 16(1):89-99. https://doi.org/10.1111/j.1365-294X. 2006.03127.x

Zhou XD, De Beer ZW, Wingfield MJ (2013) Ophiostomatoid fungi associated with conifer-infesting bark beetles in China. In: Seifert KA, De Beer ZW, Wingfield MJ (eds) The ophiostomatoid fungi: expanding frontiers. CBS Biodiversity Series, vol 12. CBS-KNAW Biodiversity Centre, Utrecht, The Netherlands, pp 91-98

\section{Publisher's Note}

Springer Nature remains neutral with regard to jurisdictional claims in published maps and institutional affiliations.
Ready to submit your research? Choose BMC and benefit from:

- fast, convenient online submission

- thorough peer review by experienced researchers in your field

- rapid publication on acceptance

- support for research data, including large and complex data types

- gold Open Access which fosters wider collaboration and increased citations

- maximum visibility for your research: over 100M website views per year

At BMC, research is always in progress.

Learn more biomedcentral.com/submissions 